\title{
Short term changes in zooplankton community during the summer-autumn transition in the open NW Mediterranean Sea: species composition, abundance and diversity
}

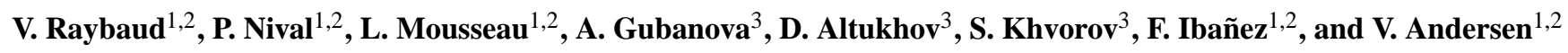 \\ ${ }^{1}$ UPMC Université Paris 06, UMR 7093, Laboratoire d'Océanographie de Villefranche, 06230 Villefranche-sur-Mer, France \\ ${ }^{2}$ CNRS, UMR 7093, LOV, 06230 Villefranche-sur-Mer, France \\ ${ }^{3}$ Plankton Department, Institute of Biology of the Southern Seas (IBSS), Nakhimov av-2, Sevastopol, 99011 Crimea, Ukraine
}

Received: 26 March 2008 - Published in Biogeosciences Discuss.: 28 May 2008

Revised: 24 September 2008 - Accepted: 17 November 2008 - Published: 16 December 2008

\begin{abstract}
Short term changes in zooplankton community were investigated at a fixed station in offshore waters of the Ligurian Sea (DYNAPROC 2 cruise, September-October 2004). Mesozooplankton were sampled with vertical WPII hauls (200 $\mu \mathrm{m}$ mesh-size) and large mesozooplankton, macrozooplankton and micronekton with a BIONESS multinet sampler (500 $\mu \mathrm{m}$ mesh-size). Temporal variations of total biomass, species composition and abundance of major taxa were studied. Intrusions of low salinity water masses were observed two times during the cruise. The first one, which was the most intense, was associated with changes in zooplankton community composition. Among copepods, the abundance of Calocalanus, Euchaeta, Heterorhabdus, Mesocalanus, Nannocalanus, Neocalanus, Pleuromamma and also calanoid copepodites increased markedly. Among noncopepod taxa, only small ostracods abundance increased. After this low salinity event, abundance of all taxa nearly returned to their initial values. The influence of salinity on each zooplankton taxon was confirmed by a statistical analysis (Perry's method). The Shannon diversity index, Pielou evenness and species richness were used to describe temporal variations of large copepod $(>500 \mu \mathrm{m})$ diversity. The Shannon index and Pielou evenness decreased at the beginning of the low salinity water intrusions, but not species richness. We suggest that low salinity water masses contained its own zooplankton community and passed through the sampling area, thus causing a replacement of the zooplankton population.
\end{abstract}

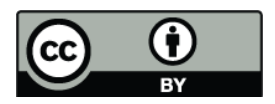

Correspondence to: V. Raybaud (raybaud@obs-vlfr.fr)

\section{Introduction}

Zooplankton play a key role in the pelagic food-web: they control carbon production through predation on phytoplankton, its export to depth by sinking of carcasses (Turner, 2002), faecal pellets (Fowler and Knauer, 1986) and vertical migrations (Longhurst, 1989; Al-Mutairi and Landry, 2001). Zooplankton community structure is highly diverse in terms of the size of organisms, their diets, their feeding modes and their behaviour. Each organism has a different effect on the flux of matter. Hence, the structural and functional diversity of zooplankton may be an important factor in carbon transport.

The abundance and specific composition of zooplankton are well documented in the NW Mediterranean Sea, but the overwhelming majority of previous studies was based on monthly sampling or large scale cruises and did not address short-term changes (Vives, 1963; Hure and Scotto di Carlo, 1968; Franqueville, 1971; Sardou et al., 1996). Only two studies addressed zooplankton dynamics at short time scales in the open Ligurian Sea (Andersen et al. 2001a and 2001b). Short term variations are more documented for phytoplankton than for zooplankton (Jouenne et al., 2007; Pannard et al., 2008).

The multidisciplinary cruise DYNAPROC 2 (DYNAmics of the rapid PROCesses in the water column) was devoted to the study of carbon production and export to depth by zooplankton organisms and physical processes during the summer-autumn transition. Monthly data acquired since 1991 at DYFAMED station, showed that summer-autumn shift generally occurred between mid-September to midOctober (Marty and Chiaverini, 2002). During the cruise,

Published by Copernicus Publications on behalf of the European Geosciences Union. 


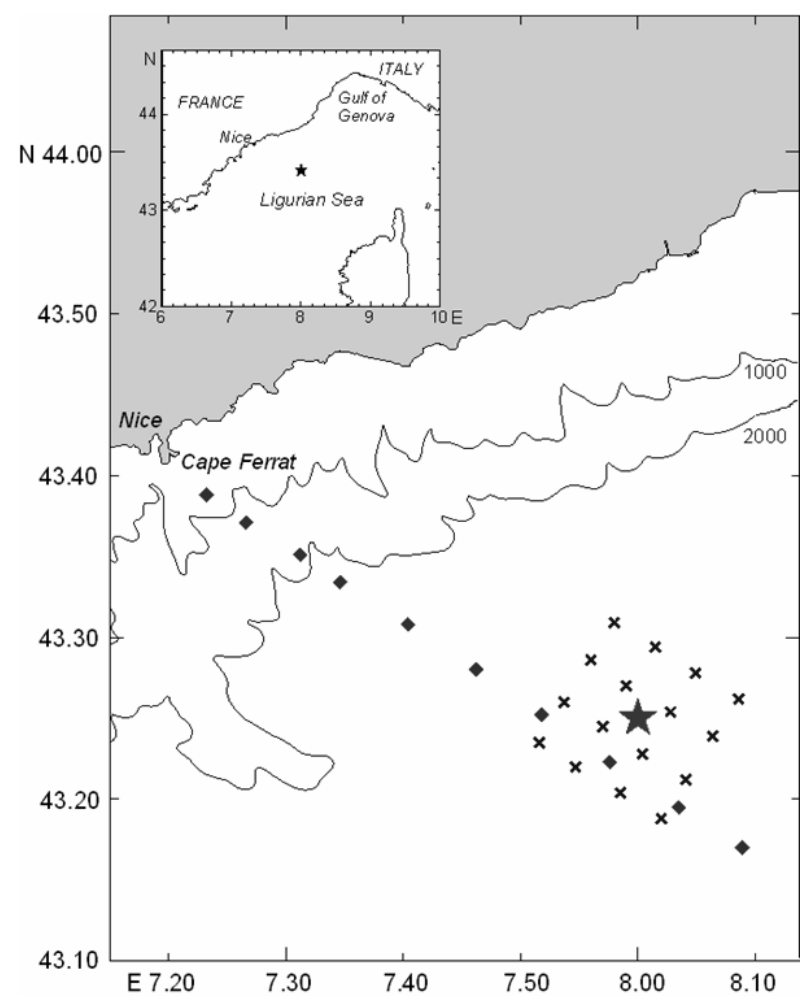

Fig. 1. Stations location of DYNAPROC 2 cruise: $(\star)$ time-series station, $(\checkmark)$ transect of eight stations performed at the beginning of the cruise to locate the time-series station, $(x)$ grid of 16 stations occupied three times during the 1-month cruise.

the sampling was performed at high frequency to study short term changes of the food-web in response to physical processes. The oceanographic cruise provided the opportunity to examine short term changes in abundance, specific composition and diversity of zooplankton community during summer-autumn transition in the open Ligurian Sea.

It is now well established that seasonal and annual variation of zooplankton structure is coupled to hydrodynamic processes. The purpose of this paper is to test the hypothesis that short-time scale changes in zooplankton abundance and diversity during the summer-autumn transition is also related to environmental features and dynamics encountered.

\section{Material and method}

\subsection{Study area}

The DYNAPROC 2 cruise was conducted in the central part of the Ligurian Sea (NW Mediterranean Sea) over a four-week period during the summer-autumn transition (14 September-17 October 2004). This period of time was selected to study the transition from stratified and oligotrophic summer conditions, to mixed and mesotrophic autumnal con- ditions. Sampling was performed at a single Time Series Station (TSS) in the central part of the Ligurian Sea, where horizontal advection is assumed to be negligible. The positioning of the TSS (28 miles offshore, $43^{\circ} 25 \mathrm{~N}, 8^{\circ} 00 \mathrm{E} ; 2350 \mathrm{~m}$ depth) was decided on the basis of a transect from coast to offshore waters. During the transect, CTD casts were performed to determine the position of the hydrodynamic front and the central waters of the Ligurian Sea. No biological samplings were performed during the transect. The objective was to locate the TSS offshore of the front. The same method was already used during DYNAPROC 1, in May 1995 (Andersen and Prieur, 2000). In addition, hydrographic parameters were measured three times at 16 stations located around the TSS (Fig. 1).

\subsection{Environmental data acquisition}

Wind speed was measured onboard with a meteorological station (sampling every $30 \mathrm{~s}$ and smoothing with a moving average with a $1 \mathrm{~h}$ window). Between the two legs, during port call, wind speed data are taken from records by MeteoFrance buoy located near the TSS, at the DYFAMED site $\left(43^{\circ} 25 \mathrm{~N}, 7^{\circ} 52 \mathrm{E}\right)$. CTD profiles (SBE 25$)$ were performed with a time interval of about 3 hours (255 profiles, temperature, salinity, pressure, fluorescence, $\mathrm{O}_{2}$, irradiance). Water sampling was done with a 12 bottles rosette to obtain samples for profiles of nutrients, chlorophyll, and others chemical parameters. In situ fluorescence was calibrated with chlorophyll- $a$ concentration measured on rosette samples by HPLC. Using the method developed by Andersen and Prieur (2000), fluorescence ( $F$, arbitrary units) was converted to chlorophyll concentration $\left(\mathrm{Chl}, \mu \mathrm{g} . \mathrm{L}^{-1}\right)$ with the following relationships:

$\begin{array}{ll}\text { Leg1:Chl }=2.0740 \times(F-0.00785) & (n=453, r=0.97)(1) \\ \text { Leg2:Chl }=1.7807 \times(F-0.00785) & (n=466, r=0.96)(2)\end{array}$

\subsection{Zooplankton sampling procedure}

\subsubsection{Zooplankton sampling}

Short-term changes in the zooplankton community were investigated with two types of nets: (i) a multiple opening and closing net with $500 \mu \mathrm{m}$ mesh nets, BIONESS (Sameoto et al., 1980); the sampled community corresponds therefore to large-sized copepods, macroplankton and micronekton; (ii) a WP-II net (200 $\mu \mathrm{m}$ mesh size), the sampled community corresponding to mesozooplankton (copepods mainly). The BIONESS was obliquely hauled over the $250-0 \mathrm{~m}$ water column (9 different strata) in the vicinity of the time-series station. WP-II sampling was performed with $200-0 \mathrm{~m}$ vertical tows at the time series station with a triple WP-II net: two samples were used for biomass analysis (Mousseau et al., 2008), the third one was formalin preserved for counting and taxonomic identification. All zooplankton samples were obtained solely at the TSS. During day, 18 samples with WP-II 
and 18 with BIONESS net were performed; during night, 17 samples with WP-II and 20 with BIONESS.

\subsubsection{Preservation, counting and taxonomic identification}

Samples were preserved with 5\% borax-buffered formalinseawater before counting and identification. For copepod taxonomy, reference was made to the species inventory for Mediterranean Sea from Razouls and Durand (1991) and the web site of Razouls et al.: http://copepodes.obs-banyuls.fr. Largest animals were picked up individually from samples, measured and counted. Each sample was diluted to the volume of 50,60 or $40 \mathrm{ml}$, depending on visually determined total zooplankton abundance. After that, $1 \mathrm{ml}$ sub-sample was taken with a calibrated Stempel-pipette in two replicates. In the sub-sample all organisms less than $1.5 \mathrm{~mm}$ were counted. Animals with a size larger than $1.5 \mathrm{~mm}$ and rare animals were counted in $1 / 2,1 / 4$ or $1 / 8$ of a sample. The largest animals were counted in the whole sample.

Species identification was not possible for all copepods, taxonomic determination is presented here at genus level. When the species could be recognized with absolute certainty, the name of the species is specified. Non-copepod taxa were counted at a taxonomic level of family or order.

Preserved WP-II samples were not available for the first part of leg 1 (17-22 September). Frozen samples, initially collected for biomass analysis were used for taxonomic identification. To defrost the samples, they were put in a beaker filled with room temperature water. As some organisms were damaged by the freezing, the taxonomic identification was less accurate. WP-II data from 17-22 September are also presented in this paper but these data are drawn in grey in the graphs (Figs. 4 to 7 ).

\subsection{Data analysis}

\subsubsection{Abundance of zooplankton}

Raw data (from BIONESS and WP-II sampling), in numbers of individuals per net, were standardized to number of individuals per square meter, depending on the section of the water column sampled (200-0 m for WP-II; $250-0 \mathrm{~m}$ for BIONESS). Abundance data from the BIONESS depth stratified hauls were integrated through the $0-250 \mathrm{~m}$ water column. In this study, we have separated copepods from the rest of zooplankton. For copepods, we only present the temporal abundance variation of main copepod genera, (i.e. genera whose abundance represents more than $1 \%$ of total copepod abundance). For the other organisms, we present temporal abundance variation of main non-copepod taxa, (i.e. taxa whose abundance represents more than $1 \%$ of total noncopepods abundance). However, a list of total individuals identified (copepods and other taxa) is presented in Appendix A.

\subsubsection{Diversity indices}

The computation of species diversity indices requires a taxonomic identification at species level. In WP-II samples, only $42 \%$ of total number of organisms could be determined at this level, making the calculation of species diversity indices impossible. The WP-II net (200 $\mu \mathrm{m}$ mesh size) caught a large number of juveniles (ratio adult to juveniles: 0.6). Identification to species level of juveniles copepods is very difficult (often not possible), which explains that only $42 \%$ of total number of organisms sampled with WP-II have been determined to species level. In contrast, the BIONESS net (500 $\mu \mathrm{m}$ mesh size) samples mainly larger organisms (adults or CV copepodits). So, $99 \%$ of copepods could be identified to species level with the BIONESS net. Consequently, species diversity indices were only calculated using copepod data obtained with this net.

Three different indices were computed: Shannon index (Shannon, 1948), Pielou evenness (Pielou, 1966), species richness. The comparison of these three indices indicates whether or not diversity variations are due to a change of the number of species, or a modification in the relative contributions of taxa, or a combined effect of these two parameters.

Shannon diversity index $\left(H^{\prime}\right)$ was computed from Eq. (3) where $s$ is the number of species and $p_{i}$ is the relative frequency of the species $i$.

$H^{\prime}=-\sum_{i=1}^{s} p_{i} \cdot \ln \left(p_{i}\right)$

Pielou evenness $(J)$ was computed by dividing $H^{\prime}$ by $\ln (s)$, as shown in formula (4):

$J=H^{\prime} / \ln (s)$

Species richness is defined as the number of species.

\subsubsection{Statistical methods}

\section{Day-night differences}

Wilcoxon-Mann-Whitney test $(p \leq 0,05)$ for non-paired samples was used on zooplankton abundance and diversity data to see if there was a significant difference between night and day. If $Z$ value was higher than the critical value 1.64 , so, the samples were not significantly different at $p=0.05$; if $Z$ value was higher than 2.33 the samples were not significantly different $p=0.01$.

\section{Relationship between zooplankton abundance and environ- mental parameters}

Perry's method was used to investigate relationships between zooplankton abundance and environmental parameters (Perry and Smith, 1994). This method allows identification of associations between each zooplankton group and an environmental factor (in this study, the integrated water column 
salinity). The range of salinity values is divided into several classes of equal size, with the number of classes adjusted such that no empty class exists. Frequencies of observations in each class are estimated and the cumulative distribution of frequencies is computed. The sum of zooplankton abundance from all samples in each salinity class is computed, and this distribution is also cumulated. The cumulative distribution of abundance of each zooplankton group, $g(t)$, was plotted against the cumulative distribution of salinity, $f(t)$. If these two distributions are almost similar, there is no significant dependence of this zooplankton group on the environmental parameter, whereas the greater their difference, the stronger is the association. A Monte Carlo randomization test was set after 10000 permutations in order to test the significance of association between $g(t)$ and $f(t)$. This method is explained in detail in Perry and Smith, 1994.

\section{Relationship between zooplankton diversity and salinity}

The method of cumulative sum of deviations from the mean, called "Cumsum" (Ibañez et al., 1993) is used for (i) detecting changes which occurred in the average level of a series, (ii) determining the date when changes appear, (iii) and estimating the average value of homogenous intervals. This method allows the division of a temporal series with slope reversals in the cumsum curve. In the present study, this method was used (i) to determine relationships between large copepod diversity and water column salinity during the cruise, (ii) to divide the temporal series of zooplankton diversity and salinity.

The temporal variations of salinity and zooplankton diversity indices (day and night) are considered as three distinct chronological series. For each series $x(i)$ of $p$ values, the variable $S p$, which is the cumulated sum of deviations from the mean $k$, is computed as shown in Eq. (5):

$S p=\sum_{i=1}^{p}\left(x_{i}-k\right)$

When $x_{i}$ is equal to the mean $k$ over a period of time, the $S p$ curve is horizontal. When $x_{i}$ remains greater than $k, S p$ curve shows a positive slope and inversely. So, the moment when the series changes relative to the mean can be detected by slope reversals.

\section{Results}

\subsection{Meteorological and environmental conditions}

Temporal variations of wind speed (Fig. 2a) was characterised by several strong wind events ( $>25$ knots). During the first part of the cruise, two from NE occurred (17 and 25 September 2004). At the end of the cruise there was a succession of three gusts of wind from opposite directions: SW, NE and SW.
The time-depth distribution of temperature (Fig. 2b) shows a highly stratified water column from the beginning of the cruise to 10 October. The thermocline was strongly marked, with a mixed-layer temperature higher than $20^{\circ} \mathrm{C}\left(22^{\circ} \mathrm{C}\right.$ during weak wind periods). This thermocline was located at approximately $25 \mathrm{~m}$ depth throughout the cruise, except at the end of the cruise (11-16 October 2004), where it deepened to $40 \mathrm{~m}$ depth during the period of successive strong wind events. The deepening of the thermocline was accompanied by a strong cooling of the mixed layer water (due to heat flux decrease) and suggests the beginning of an autumnal destratification.

The time-depth distribution of salinity (Fig. 2c) shows the occurrence of two intrusions of Low Salinity Water (LSW) during the cruise. This water likely had a coastal origin and crossed the Ligurian front along isopycnals by a barocline instability (Andersen et al., 2008). The first intrusion (LSW-1), which occurred from 21 to 30 September, was very important as well as by its size as by its intensity. LSW-1 was located between $15 \mathrm{~m}$ and $75 \mathrm{~m}$ depth. The lower value recorded was less than 38.05 , whereas average salinity at this depth lies between 38.30 and 38.40 outside the intrusion. The second intrusion (LSW-2), which occurred from 9 to 12 October, was weaker and restricted to the layer $20-40 \mathrm{~m}$. A salinity less than 38.30 was recorded during two days, and minimum salinity was not lower than 38.20.

The time-depth distribution of chlorophyll- $a$ (Fig. 2d) shows a vertical bimodal distribution during the beginning of the cruise. The deeper peak ( $80 \mathrm{~m}$ depth) was mainly composed of senescent diatoms, which quickly sedimented. The physiological state (senescent) of the diatoms was inferred from the aspect of diatom cells under the microscope (Lasternas et al., 2008). The upper peak, which was located at about $50 \mathrm{~m}$ depth, was mainly composed of nanophytoplankton. The $50 \mathrm{~m}$ peak persisted until the end of the cruise but the maximum concentration occurred at the beginning of the cruise (19-22 September). The decline coincided with the arrival of LSW-1.

\subsection{Zooplankton abundance}

\subsubsection{Total zooplankton biomass}

A detailed analysis of temporal changes in total zooplankton biomass is provided by Mousseau et al. (2008). Briefly, total zooplankton dry weight integrated over the $200-0 \mathrm{~m}$ water column varied between $0.15 \mathrm{~g} . \mathrm{m}^{-2}$ and $3.79 \mathrm{~g} . \mathrm{m}^{-2}$ (Fig. 3). As expected, night data were generally higher than day data, except for one datum (night between 18 and 19 September). This general pattern was caused by migratory organisms which are located in deep layers during day and move to the surface layer during night. In spite of a strong variability in the data, it is noticeable that average zooplankton biomass appeared higher during LSW-1. 

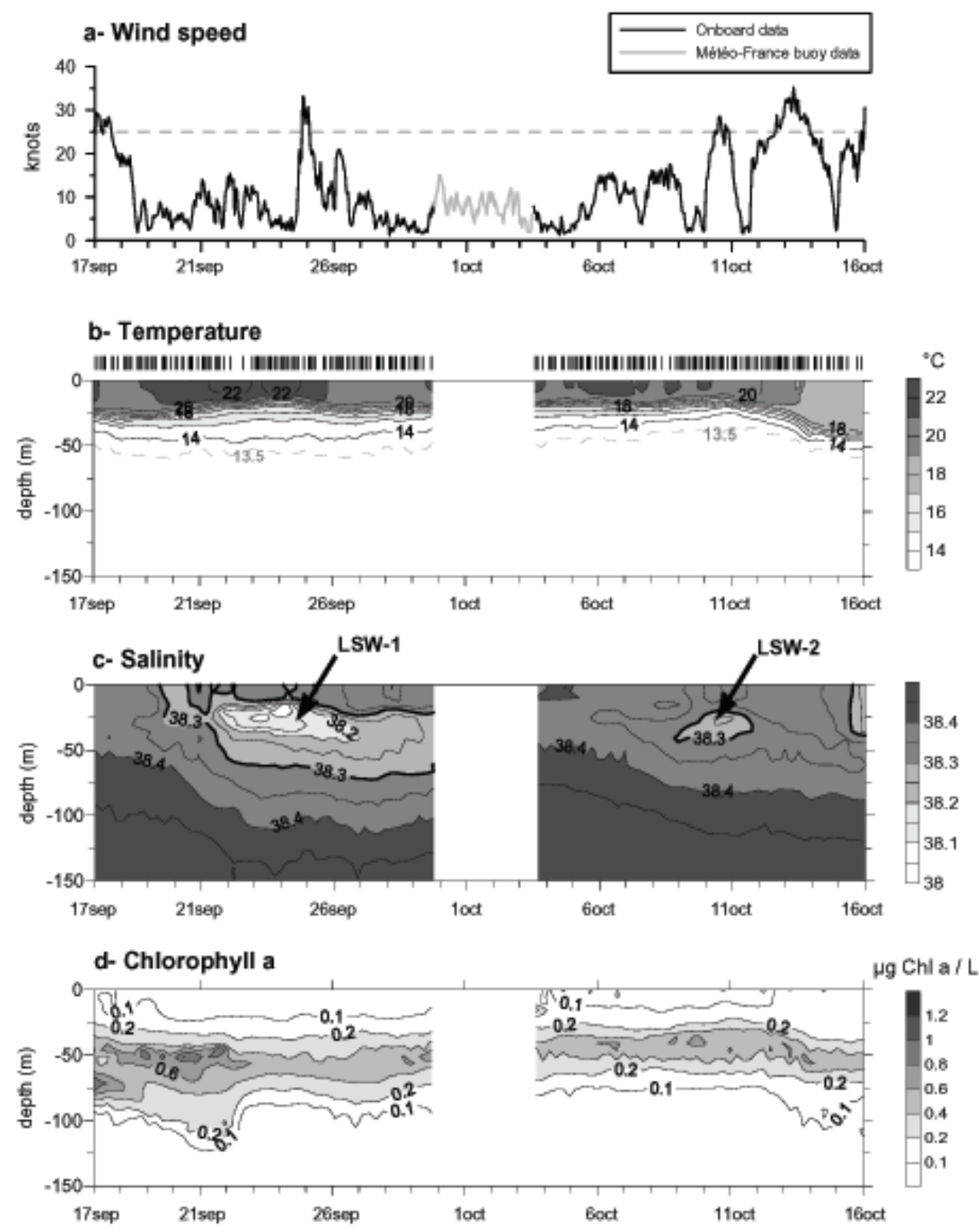

Fig. 2. Time series of meteorological and hydrological data during DYNAPROC 2 cruise. (a) 10-m wind speed in knots. (b) time-depth distribution of temperature, (c) salinity and (d) chlorophyll- $a$ recorded in the $0-150 \mathrm{~m}$ water column during the sampling period. Periods with no data correspond to port calls between the two legs.

\subsubsection{Abundance of major zooplankton taxa}

The abundance of total copepods (adults and copepodits) sampled with WP-II varied between 10000 and 45000 ind. $\mathrm{m}^{-2}$ (Fig. 4a). It reached a maximum during LSW-1, after which it nearly returned to initial values. In contrast, there were no detectable effects of LSW-2 on total copepod abundance. Copepodits, which represent more than $48 \%$ of total copepod numbers, showed the same pattern as total copepods, with a maximum of 22000 ind. $\mathrm{m}^{-2}$ during LSW-1 (Fig. 4b). When considering abundance of adults averaged over the sampling period, the genus Clausocalanus ranked first, followed by Oithona, Pleuromamma, Calocalanus and Neocalanus. The sum of these five genera represented nearly $90 \%$ of the abundance of adults. Clausocalanus spp. was mainly $C$. pergens (43\%). Its abundance did not vary a lot during the cruise but one maximum was recorded during the night between 27 and 28 September (Fig. 4c). Oithona spp. (61\% O. similis) appeared to fluctuate randomly during the study period (Fig. 4d). Pleu- 


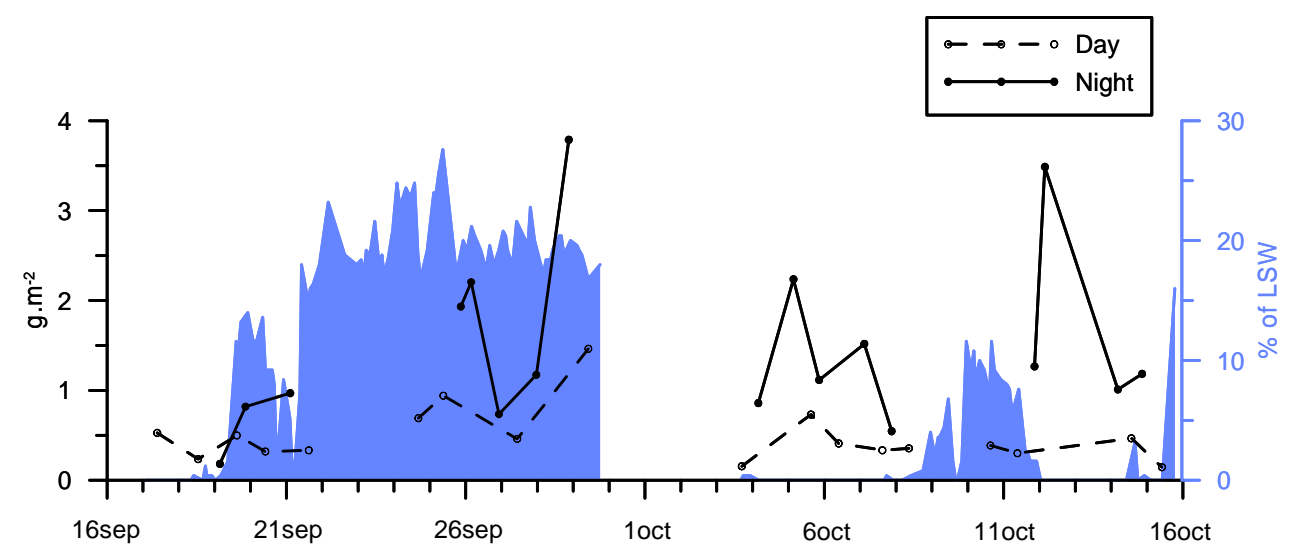

Fig. 3. In black: total zooplankton dry weight sampled with WP-II during DYNAPROC 2 cruise. In blue: percentage of the $0-200 \mathrm{~m}$ water column occupied by Low Salinity Water (LSW, <38.30).
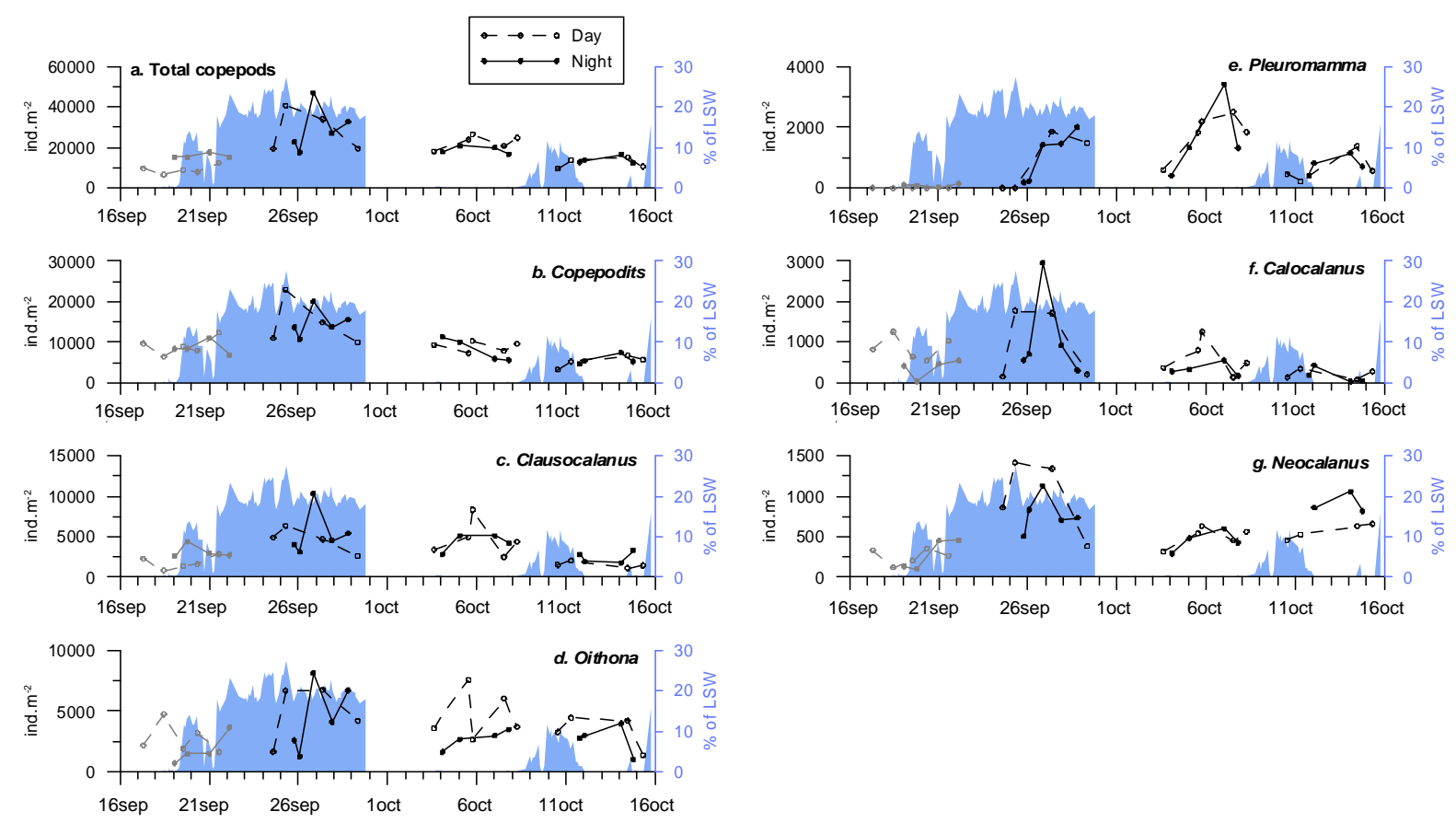

Fig. 4. Temporal variation of copepods density sampled with WP-II net during DYNAPROC 2 cruise. Dashed lines: day data; continuous lines: night data. In grey: data from frozen samples. In blue: percentage of the $0-200 \mathrm{~m}$ water column occupied by Low Salinity Water (LSW, <38.30).

romamma spp. (96\% P. abdominalis and $4 \%$ P. gracilis) had a maximum around 7 October (Fig. 4e). Neocalanus spp. (exclusively $N$. gracilis) and Calocalanus spp. show a maximum of abundance during LSW-1 (Fig. 4f-g).

Among the non-copepod taxa sampled in WP-II, the most abundant were the appendicularians, followed by pteropods, ostracods, hyperiids, chaetognaths and euphausiids (Fig. 5af). For most of these taxa, abundance fluctuated randomly without any strong relationship with either LSI-1 or 2 (Fig. 5a-f). The most striking feature was the occurrence of short term abundance peaks (each time constituted with only one point): Appendicularians (night between 28 and 29 September), Pteropods (15 October), Ostracods (night between 28 and 29 September), Hyperiids (night between 19 and 20 September), Chaetognaths (25 September). These short term variations could have been related to horizontal patchiness.

Most of the small copepods and copepodits collected with WP-II net in the size range $200-500 \mu \mathrm{m}$ did not appear in the BIONESS samples. Total abundance of 

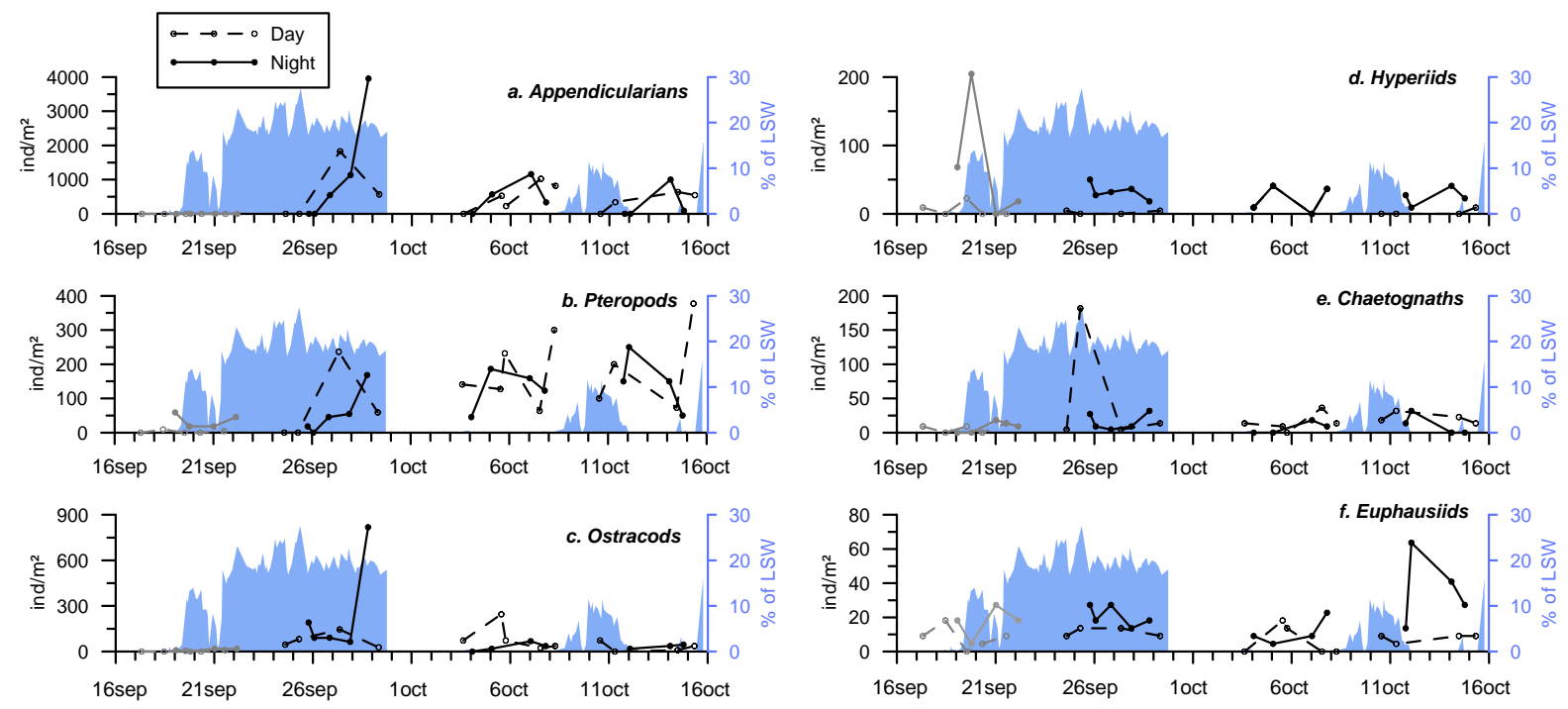

Fig. 5. Temporal variation of major non-copepods groups sampled with WP-II net during DYNAPROC 2 cruise. Dashed lines: day data; continuous lines: night data. In grey: data from frozen samples. In blue: percentage of the 0-200 m water column occupied by Low Salinity Water (LSW, <38.30).
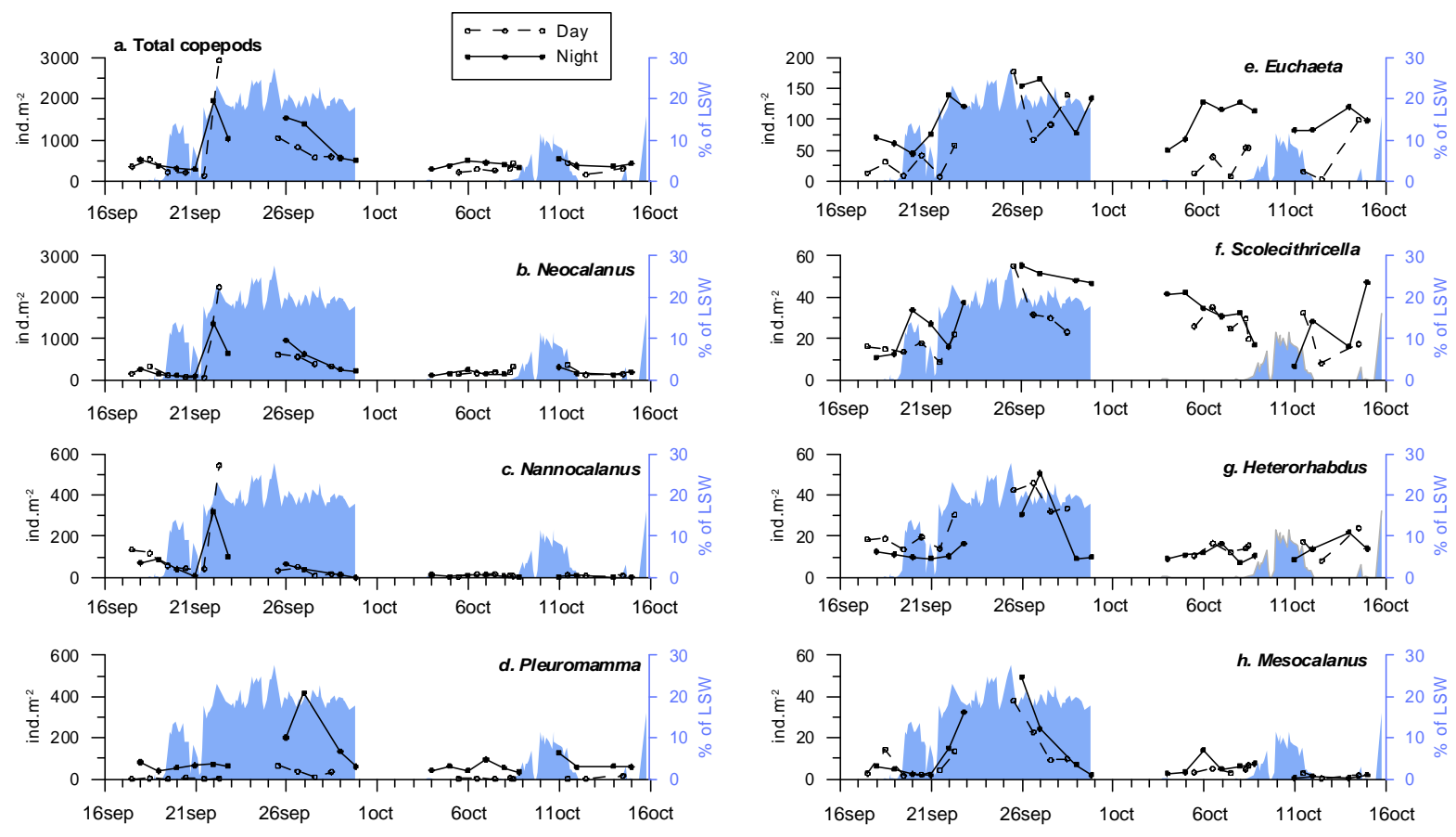

Fig. 6. Temporal variation of large copepods density sampled with BIONESS net during DYNAPROC 2 cruise. Dashed lines: day data; continuous lines: night data. In blue: percentage of the 0-250 m water column occupied by Low Salinity Water (LSW, <38.30)

large copepods sampled with this net, fluctuated around 500 ind. $^{-2}$ (Fig. 6a) but showed a strong increase on 21 September at the beginning of LSI-1 (until 3000 ind. $\mathrm{m}^{-2}$ ). Afterwards, concentrations declined until the end of LSW-1 to return nearly to the initial values. As with WP-II samples, there was no increase of total large copepods during
LSW-2. The abundance increase during LSW-1 was observed for most of the principal copepod genera, especially the dominant one: Neocalanus (Fig. 6b). This genus consisted of a single species, $N$. gracilis (as is WP-II samples) and represented more than $50 \%$ of total copepod numbers sampled with BIONESS net. It ranked first by average 

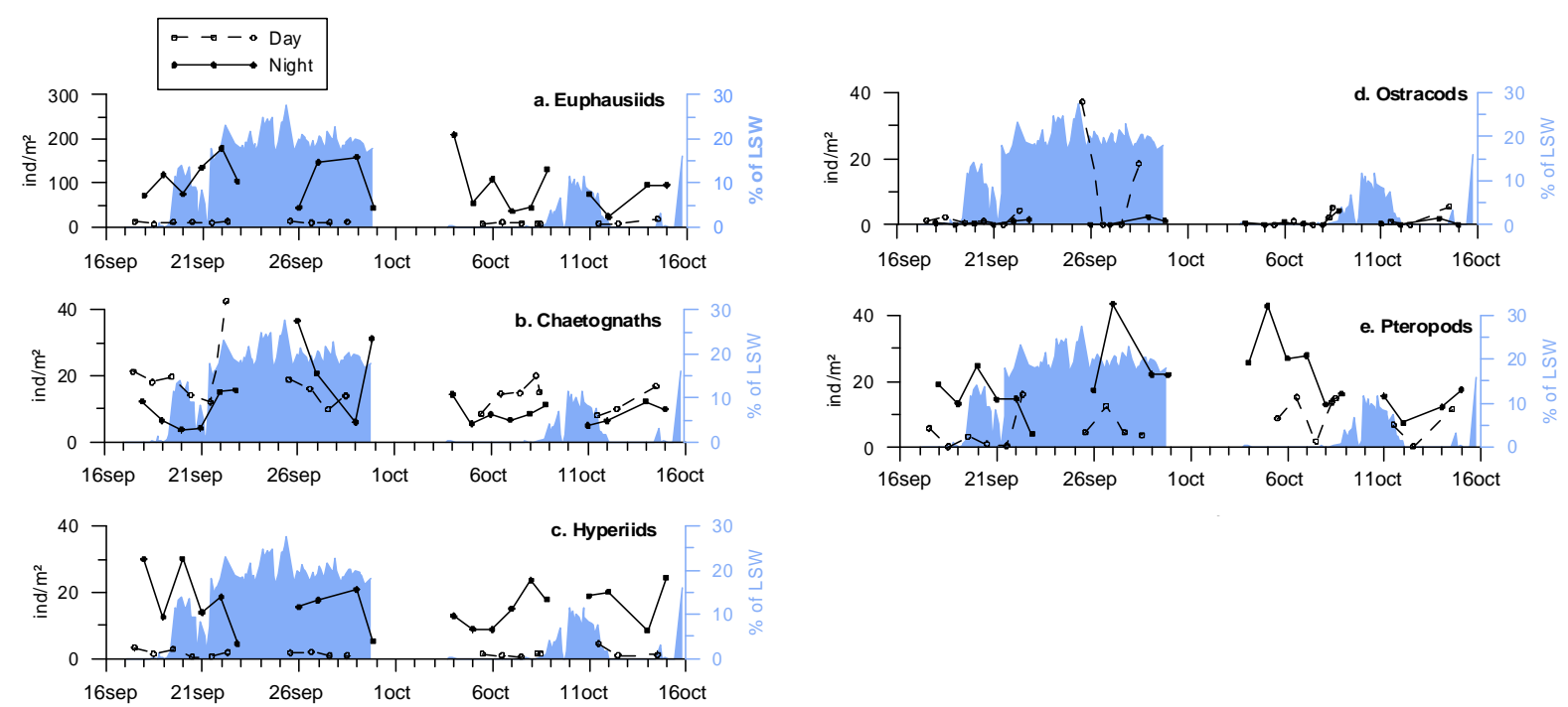

Fig. 7. Temporal variation of major non-copepods groups sampled with BIONESS net during DYNAPROC 2 cruise. Dashed lines: day data; continuous lines: night data. In blue: percentage of the $0-250 \mathrm{~m}$ water column occupied by Low Salinity Water (LSW, <38.30).

Table 1. Day-night variations in zooplankton abundance. $\mathrm{Z}$ values were calculated with a Wilcoxon-Mann-Whitney test. During day, 18 samples with WP-II and 18 with BIONESS net were performed; during night, 17 samples with WP-II and 20 with BIONESS. $n s=n o$ significant difference, $*=$ significant difference with $p \leq 0,05, * *=$ significant difference with $p \leq 0,01$.

\begin{tabular}{llll}
\hline & & WP2 & BIONESS \\
\hline Copepods & Total copepods & $0.0165^{n s}$ & $1.4471^{n s}$ \\
& Copepodits & $0.2145^{n s}$ & - \\
& Calocalanus & $1.0567^{n s}$ & - \\
& Clausocalanus & $1.5349^{n s}$ & - \\
& Euchaeta & - & $3.3474^{* *}$ \\
& Heterorhabdus & - & $-2.7920^{n s}$ \\
& Mesocalanus & - & $-0.0731^{n s}$ \\
& Nannocalanus & - & $-1.2717^{n s}$ \\
& Neocalanus & $0.8584^{n s}$ & $0.3362^{n s}$ \\
& Oithona & $1.6175^{n s}$ & - \\
& Pleuromamma & $0.6112^{n s}$ & $4.8677^{* *}$ \\
& Scolecithricella & - & $1.7395^{*}$ \\
Opther groups & - & - \\
& Chaeticularians & $0.1578^{n s}$ & - \\
& Euphausiids & $-1.0395^{n s}$ & $-2.4411^{n s}$ \\
& Hyperiids & $3.2987^{* *}$ & $5.2477^{* *}$ \\
& Ostracods & $0.514^{n s}$ & $-1.5745^{n s}$ \\
& Pteropods & $0.149^{n s}$ & $4.1368^{* *}$ \\
\hline
\end{tabular}

abundance, followed by Nannocalanus (exclusively N. minor), Pleuromamma (32\% P. abdominalis and $68 \%$ P. gracilis), Euchaeta, Scolecithricella, Heterorhabdus and Mesocalanus (exclusively M. tenuicornis). The abundance of all these taxa clearly increased with LSW-1, except for Euchaeta and Scolecithricella, for which abundance increases were less evident (Fig. 6c-h).

Among non-copepod taxa sampled with BIONESS net, the most abundant were euphausiids (50\% Nematoscelis megalops, 28\% Meganyctiphanes norvegica and 14\% Stylocheiron longicorne), followed by chaetognaths, hyperiids, ostracods and pteropods (Fig. 7a-e). As in WP-II samples, there was no clear effect of LSW-1 or 2 on these taxa. Their abundances fluctuated randomly, mostly dominated by daynight variations.

\subsubsection{Day-night variations in zooplankton abundance}

Vertical samples integrating zooplankton organisms over the upper layer $(0-200 \mathrm{~m})$ hide any migration into this depth range, so variations between day and night will reveal only taxa which are migrating out of this superficial layer during day. Among all organisms sampled with WP-II, only hyperiids and euphausiids showed a significant difference between night and day abundances (Table 1). Among largesized organisms (BIONESS samples), the difference between day and night abundance was statistically significant for euphausiids, pteropods and hyperiids and also for the copepod genera Euchaeta, Pleuromamma and Scolecithricella. These organisms crossed the low salinity layer during night, confronted with a 0.2 salinity decrease and did not modify their behavior.

Pteropods and the copepods Pleuromamma are known for their strong migratory behavior (Andersen, 2001b) and we found a significant day-night abundance variations only in BIONESS samples. This could be the consequence of two 
Table 2. Results of Perry's test, which estimate the relationship between salinity and zooplankton abundance during DYNAPROC 2 cruise. $n s=n o$ significant relationship, $*=$ significant relationship with $p \leq 0.05, * *=$ significant relationship with $p \leq 0.01$

\begin{tabular}{|c|c|c|c|c|}
\hline & & & WP2 & BIONESS \\
\hline \multirow[t]{14}{*}{ Copepods } & Total copepods & & $0.0015^{* *}$ & $<0.0001^{* *}$ \\
\hline & Copepodits & & $0.0002 * *$ & - \\
\hline & Calocalanus & & $0.014^{*}$ & - \\
\hline & Clausocalanus & & $0.0766^{n s}$ & - \\
\hline & Euchaeta & day & - & $0.006^{* *}$ \\
\hline & & night & - & $0.0684^{n s}$ \\
\hline & Heterorhabdus & & - & $0.0001 * *$ \\
\hline & Mesocalanus & & - & $<0.0001 * *$ \\
\hline & Nannocalanus & & - & $0.0177^{*}$ \\
\hline & Neocalanus & & $0.0151 *$ & $<0.0001 * *$ \\
\hline & Oithona & & $0.4431^{n s}$ & - \\
\hline & Pleuromamma & $\begin{array}{l}\text { day } \\
\text { night }\end{array}$ & $0.1152^{n s}$ & $\begin{array}{l}0.0066^{* *} \\
0.0104 *\end{array}$ \\
\hline & Scolecithricella & $\begin{array}{l}\text { night } \\
\text { day }\end{array}$ & & $0.1432^{n s}$ \\
\hline & & night & - & $0.3084^{n s}$ \\
\hline \multirow[t]{9}{*}{ Other groups } & Appendicularians & & $0.4915^{n s}$ & - \\
\hline & Chaetognaths & & $0.4734^{n s}$ & $0.0731^{n s}$ \\
\hline & Euphausiids & day & $0.5759^{n s}$ & $0.2049^{n s}$ \\
\hline & & night & $0.309^{n s}$ & $0.4815^{n s}$ \\
\hline & Hyperiids & day & $0.3052^{n s}$ & $0.9292^{n s}$ \\
\hline & & night & $0.8614^{n s}$ & $0.8445^{n s}$ \\
\hline & Ostracods & & $0.0424 *$ & $0.1098^{n s}$ \\
\hline & Pteropods & day & & $0.7318^{n s}$ \\
\hline & & night & $0.1557^{n s}$ & $0.2432^{n s}$ \\
\hline
\end{tabular}

facts: first, the large proportion of juveniles in WP-II sampled, which do not migrate out of the 0-200 m layer, and second the patchiness inducing large variability in successive samples.

\subsubsection{Relationship between zooplankton abundance and salinity}

The results of Perry's test used to examine the relationship between salinity and abundance of the different groups, are presented in Table 2 and Figs. 8 and 9. For the groups whose day-night abundance was not significantly different, Perry's test was made by merging night and day data. In contrast, day and night data were tested separately for the others. Here, salinity is used as an indicator of different water masses. A significant influence of salinity on zooplankton abundance does not mean that these organisms actively favour different salinities. It rather indicates that the distribution of zooplankton is related to different water masses.

Most of the copepods from WP-II samples were significantly influenced by salinity (Table 2): total copepods, copepodits, Calocalanus and Neocalanus. These organisms were mainly sampled during low salinity periods (Fig. 8a). About $40 \%$ of total copepods, copepodits and Neocalanus were sampled in the two first salinity classes and $50 \%$ of Calocalanus.
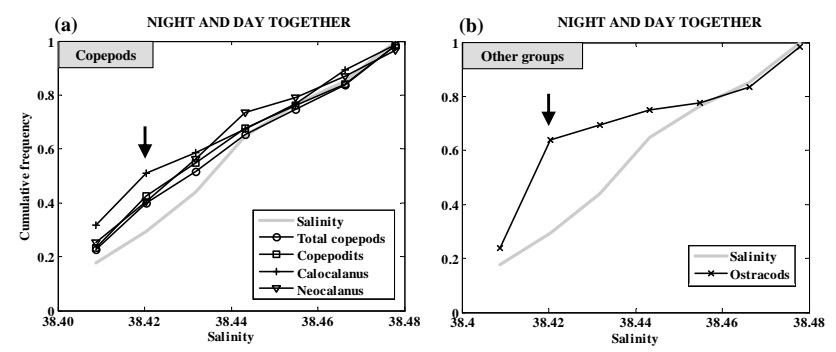

Fig. 8. Cumulative frequency distribution of different zooplankton groups sampled with WP-II net $(g(t)$, in black) in relation to salinity levels $(f(t)$, in grey). (a) copepods (b) other groups. Only taxa for which Perry's test showed a significant relationship between zooplankton abundance and salinity were plotted (Table 2). The arrow indicates the salinity class for which the greatest difference between $g(t)$ and $f(t)$ was founded. For example, in (a) more than $50 \%$ of Calocalanus spp. were sampled in the two first salinity classes.
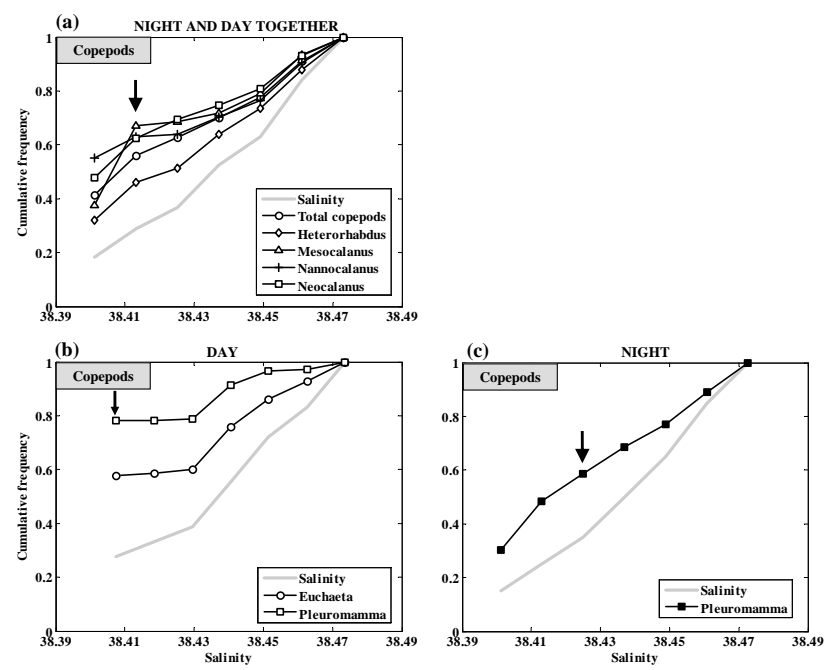

Fig. 9. Cumulative frequency distribution of copepods sampled with BIONESS net $(g(t)$, in black) in relation to salinity levels ( $f(t)$, in grey). (a) Copepods for which day and night abundances were not significantly different (day and night data were merged) (b-c) Copepods for which day and night abundances were significantly different: (b) day data, (c) night data. Only taxa for which Perry's test showed a significant relationship between zooplankton abundance and salinity were plotted (Table 2). The arrow indicates the salinity class for which the greatest difference between $g(t)$ and $f(t)$ was founded.

As with WP-II, most copepods sampled with BIONESS were significantly influenced by salinity (Table 2): total copepods, Euchaeta (day), Heterorhabdus, Mesocalanus, Nannocalanus, Neocalanus and Pleuromamma (day and night). 45 to $80 \%$ of these groups were sampled in the two first salinity classes (Fig. 9a-c).

The non-copepod taxa sampled with WP-II and BIONESS nets seemed less influenced by salinity. Only the small 
Table 3. Day-night variations in large copepods $(>500 \mu \mathrm{m}) \mathrm{di}-$ versity. $Z$ values calculated with a Wilcoxon-Mann-Whitney test. $n s=n o$ significant difference, ${ }^{*}=$ significant difference with $p \leq 0,05$, $* *=$ significant difference with $p \leq 0.01$.

\begin{tabular}{ll}
\hline & $Z$ values \\
\hline Shannon index & $3.3767 * *$ \\
Pielou evenness & $3.4936^{* *}$ \\
Species richness & $0^{n s}$ \\
\hline
\end{tabular}
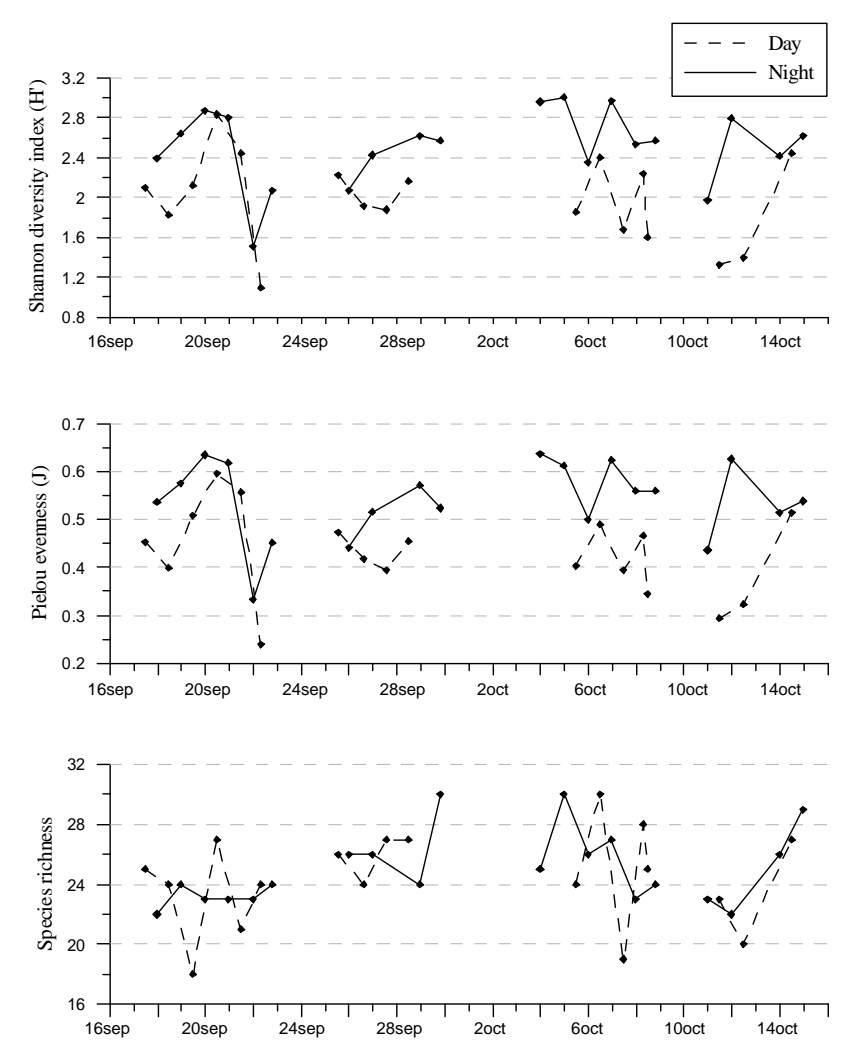

Fig. 10. Temporal variation of three diversity indices calculated on large copepods data: (a) Shannon index, (b) Pielou evenness, (c) Species richness.

ostracods $(<200 \mu \mathrm{m}$, WP-II samples) showed a significant relationship with salinity (Table 2). $50 \%$ of these organisms were sampled during the two first salinity classes (Fig. 8b).

\subsection{Diversity of large copepods}

\subsubsection{Day-night variations of diversity}

The results of Wilcoxon-Mann-Whitney test (Table 3) showed that night values of Shannon diversity index and Pielou evenness were significantly higher than day values. However, day and night species richness were not signifi-

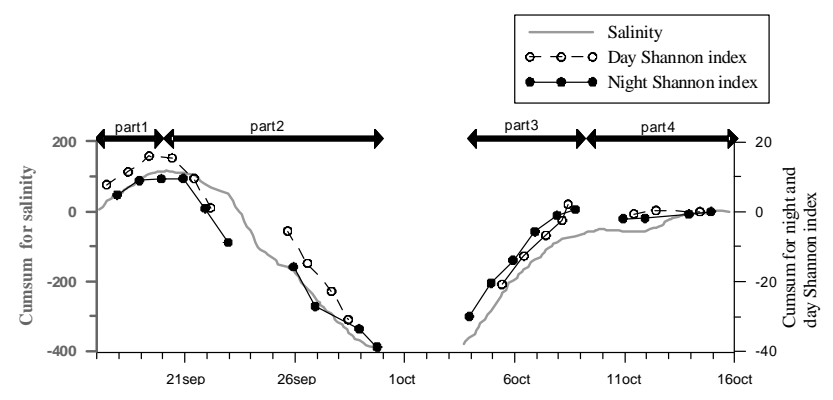

Fig. 11. Cumsum for salinity and Shannon index (night and day) calculated on large copepods (BIONESS net data) during DYNAPROC 2 cruise.

cantly different. In other terms, during the night, Shannon index and Pielou evenness values were higher but the number of species did not change. This could have been due to the migratory taxa (Euchaeta spp., Pleuromamma spp. and Scolecithricella spp.) whose abundance were low in $0-250 \mathrm{~m}$ layer during day, and are increased considerably at night.

\subsubsection{Temporal variations of large copepods diversity}

The values of the Shannon diversity index strongly varied during the time of sampling between 1.10 and 3.00 (Fig. 10). Lowest values were recorded during LSW-1, during day as well as during night. We can thus suggest that there was an impact of the LSW-1 on the copepod community structure, but this perturbation had a short duration time. The Pielou evenness varied between 0.24 and 0.64 and paralleled the Shannon diversity index. Decreases in Shannon index and Pielou evenness during LSW-1 were due to marked increases in the abundance of $N$. gracilis and $N$. minor which dominated the copepod community. The species richness (i.e. number of species) fluctuated in the range 18 to 30 , with a strong random variations from day to day. It did not decrease at the beginning of LSI-1 which confirms that shifts in diversity indices reflected changes in relative abundances of taxa within a stable community.

\subsubsection{Relationship between large copepods diversity and} salinity

Figure 11, shows the cumulated sum of deviations from the mean (Cumsum) for salinity and night and day Shannon index. All three variables showed the same pattern: slope reversals occur at the same time, which suggests that diversity changes are related to changes in salinity. Figure 11 also suggests that the sampling period can be divided in four sequences:

- Part 1 (17-20 September): slopes are positives, which mean that successive values are above the mean as well as for salinity than for Shannon index. 
- Part 2 (20-30 September): negative slopes, which indicate values under the mean for salinity and diversity. This is the LSW-1 period.

- Part 3 (4-9 October): slopes become positives again, which indicates the end of LSW-1. Copepods community is returning to its undisturbed state.

- Part 4 (9-16 October): slopes are close to zero. There is no effect of LSW-2. Copepods community structure comes back to its initial values; salinity and diversity are stable.

\section{Discussion}

\subsection{Comparison with previous studies}

Although NW Mediterranean zooplankton has been the object of many studies, we have chosen to limit the comparison with the DYNAPROC 1 cruise because it is the only study with the same sampling strategy. The other studies which dealt with zooplankton in the Ligurian Sea did not have the same sampling strategy and the same temporal and spatial scales than DYNAPROC 2. For example, Pinca and Dallot (1995) explored the geographical distribution of zooplankton in the Ligurian Sea in spring but they presented the abundance (in ind. $\mathrm{m}^{-3}$ ) in the whole collection, including coastal, frontal and offshore stations. Sardou et al. (1996) studied the seasonal variations in abundance of macroplankton in the NW Mediterranean Sea but they used a $1 \mathrm{~cm}$ mesh-size net; Gasser et al. (1998) studied zooplankton on a coastal-offshore transect in the Ligurian Sea but they focused their study on the vertical distribution and did not consider short time-scale variations. Mcgehee et al. (2004) studied several physical and biological parameters in the whole Ligurian Sea (37 stations) but zooplankton were counted at only 3 stations and they did not consider temporal variations of zooplankton abundance. Consequently, the study of Andersen et al. (2001a, b) which presents short-term variation of zooplankton abundance in the central part of the Ligurian Sea during one month (DYNAPROC 1 cruise), appears the only study with which a reasonable comparison is possible.

Their study took place in May 1995 (DYNAPROC 1 cruise), which permits comparison of zooplankton community dynamics at the same place during two different seasonal transitions: late spring-summer and summer-autumn. We will present here the similarities and the differences between the two zooplankton communities observed.

In the study of Andersen et al. (2001a), total copepod abundance sampled with WP-II fluctuated between 15000 and 50000 ind. $\mathrm{m}^{2}$. During DYNAPROC 2, the range of values is very similar: $10000-45000$ ind. $\mathrm{m}^{2}$. The comparison of major taxa sampled during DYNAPROC 1 (late springsummer) and DYNAPROC 2 (summer-autumn) reveals that
Table 4. Comparison of average numbers of individuals $\mathrm{m}^{-2}$ of major copepods taxa sampled with WP-II net during DYNAPROC 1 (May 1995) and DYNAPROC 2 (September-October 2004) cruises.

\begin{tabular}{lll}
\hline Genus & DYNAPROC 1 & DYNAPROC 2 \\
\hline & $\left(\right.$ Ind.m $\left.^{-2}\right)$ & $\left(\right.$ Ind.m $\left.^{-2}\right)$ \\
Clausocalanus & 10298 & 3559 \\
Neocalanus & 363 & 581 \\
Oithona & 11877 & 3474 \\
Pleuromamma & 883 & 860 \\
\hline
\end{tabular}

the two periods shared a great number of taxa: Clausocalanus, Euchaeta, Heterorhabdus, Neocalanus, Oithona and Pleuromamma. The comparison of the abundance of major copepods taxa during DYNAPROC 1 and DYNAPROC 2 (Table 4) is possible only with WP-II net because the layers sampled were the same during the two cruises $(200-$ $0 \mathrm{~m}$ ), which is not the case with BIONESS net $(980-0 \mathrm{~m}$ for DYNAPROC 1 and $250-0 \mathrm{~m}$ in this study). The genera Clausocalanus and Oithona were three time less abundant during DYNAPROC 2. However, abundance of Neocalanus and Pleuromamma were of the same order of magnitude. Andersen et al. (2001a) reported the presence of Calanus helgolandicus, Centropages typicus and Monacilla typica among the major species during DYNAPROC 1 with a relative abundance respectively of $28.5 \%, 1.3 \%$ and $4.5 \%$. Although these three taxa were found during DYNAPROC 2 , their abundance was very low $(0.25 \% C$. helgolandicus, $0.20 \%$ C. typicus and $0.03 \%$ M. typica). C. helgolandicus overwinters at $400-800 \mathrm{~m}$ depth at the period of the year studied (Bonnet et al., 2005) and M. typica is a deep-living species (Andersen et al., 2001a), which could explain their low abundance in the $0-250 \mathrm{~m}$ layer. C. typicus is a spring species whose abundance decreases during summer (Mazzocchi et al., 2007), and it becomes rare in autumn.

Mesocalanus is the only genus which appears among the major taxa found during DYNAPROC 2 but not during DYNAPROC 1 . The abundance of this species is low outside LSW-1 $\left(<10\right.$ ind. $\left.\mathrm{m}^{-2}\right)$ but it increased during the low salinity event. Without the increase during LSW-1, Mesocalanus would not have been among the major taxa in DYNAPROC 2 cruise. During DYNAPROC 2 cruise, all individuals from the genus Mesocalanus belong to the species tenuicornis. M. tenuicornis is an oceanic species which was collected in all temperate and subtropical waters (Beaugrand et al., 2002; Keister et al., 2003; Morgan et al., 2003; Mackas et al., 2005). In the Ligurian Sea, Pinca and Dallot (1995) suggested that the central zone is favourable environment for the development of the large copepods species like M. tenuicornis. However, Mcgehee et al. (2004), who studied the spatial distribution of copepods in the Ligurian Sea, shows that (i) this species is not totally absent from the coastal zone, (ii) 


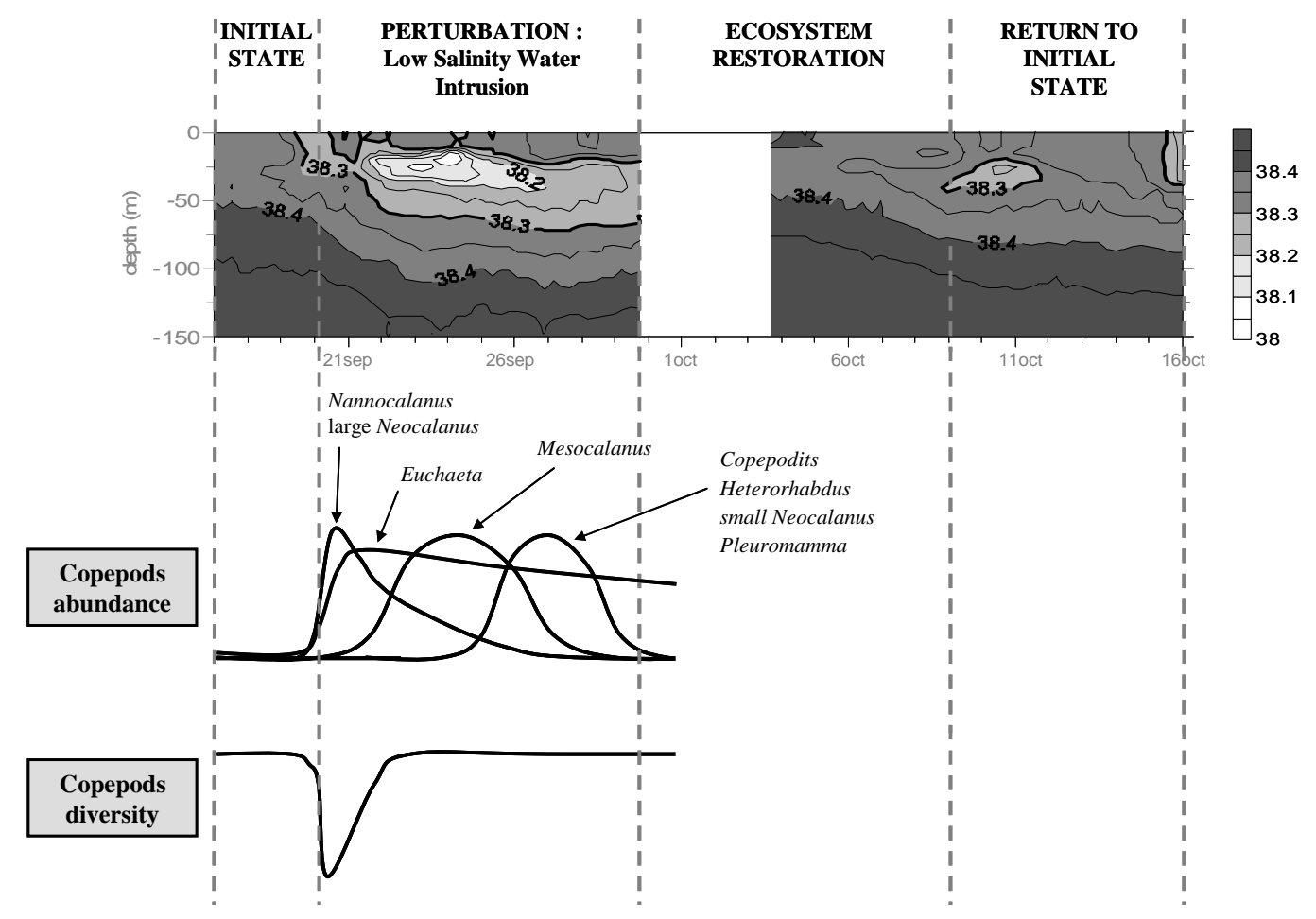

Fig. 12. Summarized scheme of the effect of LSW-1 on copepods community during DYNAPROC 2 cruise.

in two stations of the central part of the Ligurian Sea, this species is absent in one station and present in large numbers in the other. Meanders in the frontal structure might explain the differences in the spatial position of the maximum of abundance for some copepod species (Boucher et al., 1987). For DYNAPROC 2 cruise, we suggest that $M$. tenuicornis found favourable conditions in the low salinity water mass and were displaced with the water displacement.

\subsection{Impact of LSW on zooplankton community}

The sampling site of DYNAPROC 2 cruise was located near the permanent DYFAMED time-series station. For many years, this offshore site was thought to be protected from coastal inputs by the presence of the Ligurian current flowing along the coast (Béthoux and Prieur, 1983; Sournia et al., 1990; Marty and Chiaverini, 2002). Recently, Stewart et al. (2007) formulated the possibility of lateral processes at DYFAMED site (transport of particles along isopycnals or intrusion of shelf waters to the site) to explain the disparity in their sediment traps data. The DYNAPROC 2 cruise data brings some arguments in favour of the shelf water intrusion hypothesis. These observations are the first ones which show clearly the dynamics of such intrusion in the central part of the Ligurian Sea.

The results of our study showed that the arrival of LSW1 in the sampling area was associated with changes in the copepod community. We suggest that LSW-1 contained its own zooplankton community and passed through the sampling area, thus causing a community replacement. There were no taxonomic changes but rather only an abundance increase of some groups and a decrease in the diversity, in terms of evenness, of large copepods. The LSW-1 did not bring any new group of zooplankton: all taxonomic groups found during LSW-1 were also sampled outside the intrusion. The zooplankton community was not the only trophic level affected by LSW intrusions during the cruise. A significant positive effect on total bacterial abundance and production was shown (Mével et al., 2008). Changes in phytoplankton community were revealed (Lasternas et al., 2008) and these authors also noted the presence of a coastal species Scrippsiella sp. during LSW intrusions. Similar patterns of community organization of Ceratium, tintinnids and mesozooplankton during the cruise were showed in a recent study (Raybaud et al., 2008).

The changes in zooplankton community during DYNAPROC 2 are summarised in Fig. 12. The temporal segmentation of the cruise was obtained from the cumsum on salinity (part 3.3.3). Among the taxa which were significantly associated with salinity, the increase of abundance did not occurred exactly at the same time for all groups. The different lags in the timing of the variations of several copepod taxa suggest different characteristics at the beginning, in the middle and at the end of LSW-1. Nannocalanus and large Neocalanus strongly increased in abundance at the beginning of LSW-1 but their abundance decreased quickly 
after this event. Euchaeta also increased at the beginning of LSW-1 but its abundance stayed high throughout the intrusion. Mesocalanus increased at the middle of the intrusion but decreased immediately. The abundance increase of undetermined copepodits, Heterorhabdus, small Neocalanus and Pleuromamma occurred at the end of LSW-1 and had a short duration. A decrease in measures of the diversity of large copepods diversity (Shannon index and Pielou evenness) was visible only at the beginning of LSW-1.

Although we observed an increase in copepod abundance during LSW-1, the increase is unlikely to represent a preference for low salinity waters. Rather, zooplankton is strongly influenced by currents and hydrodynamic. Salinity is, in fact, a marker which indicates the arrival of different water masses containing different populations. The increase of zooplankton abundance during LSW-1 cannot be explained by reproduction for two reasons. First, the increase occurred too fast and second, high abundance did not last a long time as the zooplankton community returned to its initial structure a few days after LSW-1, before the end of the cruise.

Kelly-Gerreyn et al. (2006) studied low salinity water intrusions in the western English Channel but their study had a physical orientation. They investigated the origin, the transport and the occurrence of such intrusions but did not address biological aspects.

The offshore transport of coastal species has been extensively studied in upwelling systems. Some copepods species have a life cycle linked to transport water from the coast to offshore, such as Calanoides carinatus (Peterson, 1999). For such a system, there must be a match between the upwelling time scale and the life cycle of copepods time scale. In our study, the time and space-scale is much smaller than in an upwelling system. We observed a coastal water "lens" with a thickness not exceeding $50 \mathrm{~m}$, which crossed the sampling area in only 9 days, which is shorter than the lifetime of large copepods. The time and space-scale are so different that we cannot compare our study to an upwelling system. Moreover, LSW intrusions appear as a short-time scale perturbation; thereafter, the ecosystem returns to its initial characteristics.

\section{Conclusions}

DYNAPROC 2 cruise was initially devoted to study, at short time scales, how ecosystems switch from summer oligotrophy to autumnal mesotrophy in the Ligurian Sea, and notably the effect of wind forcing on mixing. Monthly data acquired since 1991 at DYFAMED station, showed that summerautumn shift generally occurred between mid-September to mid-October (Marty and Chiaverini, 2002). In 2004 (the year of DYNAPROC 2 cruise), the seasonal shift occurred late and the destratification due to wind started only five days before the end of the cruise, which is too short to study its effect on zooplankton community. However, a marked phenomenon was recorded during the cruise: the intrusion of coastal LSW two times in the sampling area, which was thought to be protected from coastal water by Ligurian current flow. Although the authors of a recent study (Stewart et al., 2007) proposed the existence of such coastal intrusions existence at the DYFAMED station, they have never been observed before DYNAPROC 2. The cruise lasted only one month but two coastal water intrusions were observed, which suggest that the central part is not as isolated as thought by Béthoux and Prieur (1983).

Our study documents a marked effect of coastal LSW intrusion on the offshore zooplankton community of the Ligurian Sea, and therefore its potential effect on the vertical flux of matter. Zooplankton greatly contributes to the flux of to deep layers through faecal pellets and daily migration (Conte et al., 2001). J. C. Miquel studied particle flux with sediment trap during DYNAPROC 2 cruise (personal communication, DYNAPROC 2 workshop, 5-6 July 2005). At $200 \mathrm{~m}$ depth the total mass flux showed important changes during LSW-1, when zooplankton abundance increased. From day 262 to 268 , the average total mass flux was $30 \mathrm{mg} \cdot \mathrm{m}^{-2} \cdot \mathrm{d}^{-1}$. However, after the low salinity event, the average total mass flux was about half the preceding value (fluctuated around $\left.15 \mathrm{mg} \cdot \mathrm{m}^{-2} \cdot \mathrm{d}^{-1}\right)$. These high values of mass flux during LSW-1 could be caused by the different water masses but their timing corresponds with the increase of zooplankton abundance in the 0-200 $\mathrm{m}$ layer.

Consequently, it seems necessary to multiply high frequency studies or automatic measurements in this area in the aim (i) to determine the frequency occurrence of LSW intrusions in the central part of the Ligurian Sea, (ii) and to confirm their influence on the ecosystem. 
Table A1. List of copepod species sampled with WP-II net (200 $\mu \mathrm{m}$ mesh-size) during DYNAPROC 2 cruise. Parts 1 to 4 are the time sequences defined in paragraph 3.3.3. $N$ is the number of samples. Abundances are expressed in number of individuals per meter square integrating through the layer 0-200 m: average (min;max).

\begin{tabular}{|c|c|c|c|c|c|c|c|c|}
\hline \multirow[t]{2}{*}{ Copepods WP-II (ind.m ${ }^{-2}$ ) } & \multicolumn{2}{|c|}{ Part 1} & \multicolumn{2}{|c|}{ Part 2} & \multicolumn{2}{|c|}{ Part 3} & \multicolumn{2}{|c|}{ Part 4} \\
\hline & Day & Night & Day & Night & Day & Night & Day & Night \\
\hline & $N=4$ & $N=2$ & $N=5$ & $N=7$ & $N=5$ & $N=4$ & $N=4$ & $N=4$ \\
\hline Acartia danae & $1.1(0 ; 4.5)$ & $0(0 ; 0)$ & $0(0 ; 0)$ & $0.6(0 ; 4.5)$ & $3.6(0 ; 18.2)$ & $0(0 ; 0)$ & $0(0 ; 0)$ & $0(0 ; 0)$ \\
\hline Acartia negligens & $20.5(0 ; 63.6)$ & $4.5(0 ; 9.1)$ & $34.5(0 ; 54.5)$ & $26(0 ; 72.7)$ & $0(0 ; 0)$ & $14.8(0 ; 36.4)$ & $9.1(0 ; 36.4)$ & $0(0 ; 0)$ \\
\hline Acartia spp. & $20.5(0 ; 45.5)$ & $9.1(0 ; 18.2)$ & $20(0 ; 72.7)$ & $13(0 ; 36.4)$ & $0(0 ; 0)$ & $6.8(0 ; 18.2)$ & $11.4(0 ; 36.4)$ & $0(0 ; 0)$ \\
\hline Aetideus armatus & $0(0 ; 0)$ & $2.3(0 ; 4.5)$ & $0(0 ; 0)$ & $2.6(0 ; 9.1)$ & $3.6(0 ; 18.2)$ & $1.1(0 ; 4.5)$ & $0(0 ; 0)$ & $2.3(0 ; 9.1)$ \\
\hline Aetideus giesbrechti & $0(0 ; 0)$ & $0(0 ; 0)$ & $0(0 ; 0)$ & $5.2(0 ; 36.4)$ & $1.8(0 ; 9.1)$ & $1.1(0 ; 4.5)$ & $0(0 ; 0)$ & $0(0 ; 0)$ \\
\hline Aetideus spp. & $0(0 ; 0)$ & $0(0 ; 0)$ & $0(0 ; 0)$ & $0(0 ; 0)$ & $0.9(0 ; 4.5)$ & $0(0 ; 0)$ & $0(0 ; 0)$ & $0(0 ; 0)$ \\
\hline Calanoid copepodits & 8221.6 & 8306.8 & 14172.7 & 13059.7 & 8841.8 & 8180.7 & 5160.2 & 5670.5 \\
\hline & $(6477.3 ; 9681.8)$ & $(8295.5 ; 8318.2)$ & $(9886.4 ; 22909.1)$ & $(6818.2 ; 20000)$ & $(7240.9 ; 10227.3)$ & $(5568.2 ; 11272.7)$ & $(3181.8 ; 6636.4)$ & $(4636.4 ; 7363.6)$ \\
\hline Calocalanus spp. & $\begin{array}{l}812.5 \\
(545.5 ; 1250)\end{array}$ & $\begin{array}{l}218.2 \\
(27.3 ; 409.1)\end{array}$ & $\begin{array}{l}970 \\
(145.5 ; 1772.7)\end{array}$ & $\begin{array}{l}917.5 \\
(300 ; 2954.5)\end{array}$ & $\begin{array}{l}604.5 \\
(127.3 ; 1250)\end{array}$ & $\begin{array}{l}328.4 \\
(168.2 ; 545.5)\end{array}$ & $\begin{array}{l}203.4 \\
(72.7 ; 340.9)\end{array}$ & $\begin{array}{l}169.3 \\
(27.3 ; 422.7)\end{array}$ \\
\hline Centropages spp. & $0(0 ; 0)$ & $0(0 ; 0)$ & $4.5(0 ; 13.6)$ & $0(0 ; 0)$ & $0.9(0 ; 4.5)$ & $0(0 ; 0)$ & $0(0 ; 0)$ & $0(0 ; 0)$ \\
\hline Centropages typicus & $28.4(9.1 ; 36.4)$ & $56.8(50 ; 63.6)$ & $32.7(0 ; 59.1)$ & $79.2(0 ; 309.1)$ & $16.4(0 ; 22.7)$ & $20.5(0 ; 36.4)$ & $25(9.1 ; 36.4)$ & $18.2(0 ; 36.4)$ \\
\hline Centropages violaceus & $0(0 ; 0)$ & $0(0 ; 0)$ & $0.9(0 ; 4.5)$ & $0(0 ; 0)$ & $0(0 ; 0)$ & $0(0 ; 0)$ & $0(0 ; 0)$ & $0(0 ; 0)$ \\
\hline Chiridius poppei & $0(0 ; 0)$ & $13.6(0 ; 27.3)$ & $0(0 ; 0)$ & $24(0 ; 45.5)$ & $8.2(0 ; 22.7)$ & $\begin{array}{l}23.9 \\
(13.6 ; 36.4)\end{array}$ & $0(0 ; 0)$ & $\begin{array}{l}63.6 \\
(27.3 ; 109.1)\end{array}$ \\
\hline Clausocalanus spp. & $\begin{array}{l}1546.6 \\
(813.6 ; 2363.7)\end{array}$ & $\begin{array}{l}3900 \\
(2950 ; 4850)\end{array}$ & $\begin{array}{l}4372.6 \\
(813.6 ; 9286.3)\end{array}$ & $\begin{array}{l}4877.6 \\
(1931.8 ; 11681.8)\end{array}$ & $\begin{array}{l}5458.1 \\
(2004.6 ; 14181.7)\end{array}$ & $\begin{array}{l}4471.9 \\
(2800 ; 5477.2)\end{array}$ & $\begin{array}{l}1547.8 \\
(1013.7 ; 2227.3)\end{array}$ & $\begin{array}{l}2577 \\
(1063.7 ; 3927.2)\end{array}$ \\
\hline Clytemnestra rostrata & $0(0 ; 0)$ & $0(0 ; 0)$ & $0(0 ; 0)$ & $19.5(0 ; 136.4)$ & $0(0 ; 0)$ & $0(0 ; 0)$ & $0(0 ; 0)$ & $0(0 ; 0)$ \\
\hline Clytemnestra spp. & $\begin{array}{l}70.5 \\
(54.5 ; 90.9)\end{array}$ & $\begin{array}{l}54.5 \\
(54.5 ; 54.5)\end{array}$ & $80(0 ; 200)$ & $61.1(0 ; 21802$ & $\begin{array}{l}72.7 \\
(18.2 ; 145.5)\end{array}$ & $\begin{array}{l}69.3 \\
(22.7 ; 90.9)\end{array}$ & $43.2(0 ; 81.8)$ & $\begin{array}{l}47.7 \\
(9.1 ; 109.1)\end{array}$ \\
\hline Copepoda nauplii & $\begin{array}{l}170.5 \\
(0 ; 681.8)\end{array}$ & $\begin{array}{l}954.5 \\
(0 ; 1909.1)\end{array}$ & $29.1(0 ; 109.1)$ & $\begin{array}{l}140.9 \\
(0 ; 454.5)\end{array}$ & $37.3(0 ; 113.6)$ & $22.7(0 ; 54.5)$ & $60.2(0 ; 113.6)$ & $\begin{array}{l}109.1 \\
(54.5 ; 136.4)\end{array}$ \\
\hline Corycaeidae gen. spp. & $2.3(0 ; 9.1)$ & $6.8(0 ; 13.6)$ & $5.5(0 ; 27.3)$ & $63.7(0 ; 272.7)$ & $0(0 ; 0)$ & $0(0 ; 0)$ & $6.8(0 ; 27.3)$ & $0(0 ; 0)$ \\
\hline Corycaeus furcifer & $1.1(0 ; 4.5)$ & $0(0 ; 0)$ & $2.7(0 ; 9.1)$ & $3.9(0 ; 13.6)$ & $7.3(0 ; 27.3)$ & $3.4(0 ; 9.1)$ & $2.3(0 ; 9.1)$ & $0(0 ; 0)$ \\
\hline Corycaeus spp. & $2.3(0 ; 9.1)$ & $9.1(0 ; 18.2)$ & $\begin{array}{l}208.2 \\
(0 ; 540.9)\end{array}$ & $29.2(0 ; 59.1)$ & $46.4(0 ; 100)$ & $43.2(0 ; 127.3)$ & $28.4(0 ; 90.9)$ & $20.5(0 ; 45.5)$ \\
\hline Corycaeus typicus & $0(0 ; 0)$ & $0(0 ; 0)$ & $0.9(0 ; 4.5)$ & $0(0 ; 0)$ & $0(0 ; 0)$ & $0(0 ; 0)$ & $0(0 ; 0)$ & $0(0 ; 0)$ \\
\hline Ctenocalanus vanus & $4.5(0 ; 18.2)$ & $0(0 ; 0)$ & $\begin{array}{l}52.7 \\
(9.1 ; 127.3)\end{array}$ & $\begin{array}{l}76.6 \\
(18.2 ; 227.3)\end{array}$ & $\begin{array}{l}88.2 \\
(4.5 ; 163.6)\end{array}$ & $\begin{array}{l}190.9 \\
(90.9 ; 290.9)\end{array}$ & $\begin{array}{l}34.1 \\
(18.2 ; 45.5)\end{array}$ & $27.3(0 ; 72.7)$ \\
\hline Eucalanus spp. & $0(0 ; 0)$ & $0(0 ; 0)$ & $0(0 ; 0)$ & $0(0 ; 0)$ & $0(0 ; 0)$ & $0(0 ; 0)$ & $0(0 ; 0)$ & $1.1(0 ; 4.5)$ \\
\hline Euchaeta acuta & $\begin{array}{l}71.6 \\
(31.8 ; 145.5)\end{array}$ & $\begin{array}{l}140.9 \\
(127.3 ; 154.5)\end{array}$ & $\begin{array}{l}70.9 \\
(22.7 ; 122.7)\end{array}$ & $198(0 ; 604.6)$ & $\begin{array}{l}56.4 \\
(4.5 ; 113.6)\end{array}$ & $\begin{array}{l}137.5 \\
(95.4 ; 209.1)\end{array}$ & $\begin{array}{l}92 \\
(36.4 ; 136.4)\end{array}$ & $\begin{array}{l}217.1 \\
(145.5 ; 268.1)\end{array}$ \\
\hline Euchaeta norvegica & $0(0 ; 0)$ & $0(0 ; 0)$ & $0(0 ; 0)$ & $0(0 ; 0)$ & $0(0 ; 0)$ & $1.1(0 ; 4.5)$ & $0(0 ; 0)$ & $0(0 ; 0)$ \\
\hline Euchirella messinensis & $0(0 ; 0)$ & $9.1(0 ; 18.2)$ & $0(0 ; 0)$ & $2.6(0 ; 13.6)$ & $3.6(0 ; 13.6)$ & $3.4(0 ; 4.5)$ & $0(0 ; 0)$ & $1.1(0 ; 4.5)$ \\
\hline Euchirella spp. & $0(0 ; 0)$ & $0(0 ; 0)$ & $0(0 ; 0)$ & $0.6(0 ; 4.5)$ & $0(0 ; 0)$ & $0(0 ; 0)$ & $0(0 ; 0)$ & $0(0 ; 0)$ \\
\hline Farranula spp. & $0(0 ; 0)$ & $0(0 ; 0)$ & $1.8(0 ; 9.1)$ & $0(0 ; 0)$ & $0(0 ; 0)$ & $0(0 ; 0)$ & $0(0 ; 0)$ & $0(0 ; 0)$ \\
\hline Haloptilus acutifrons & $0(0 ; 0)$ & $0(0 ; 0)$ & $0(0 ; 0)$ & $0(0 ; 0)$ & $0(0 ; 0)$ & $1.1(0 ; 4.5)$ & $0(0 ; 0)$ & $0(0 ; 0)$ \\
\hline Haloptilus longicornis & $0(0 ; 0)$ & $0(0 ; 0)$ & $2.7(0 ; 13.6)$ & $19.5(0 ; 90.9)$ & $4.5(0 ; 18.2)$ & $4.5(0 ; 18.2)$ & $2.3(0 ; 9.1)$ & $0(0 ; 0)$ \\
\hline Haloptilus spp. & $0(0 ; 0)$ & $0(0 ; 0)$ & $28.2(0 ; 140.9)$ & $0.6(0 ; 4.5)$ & $7.3(0 ; 36.4)$ & $0(0 ; 0)$ & $5.7(0 ; 18.2)$ & $4.5(0 ; 18.2)$ \\
\hline Harpacticoida & $34.1(0 ; 136.4)$ & $0(0 ; 0)$ & $0(0 ; 0)$ & $0(0 ; 0)$ & $0(0 ; 0)$ & $0(0 ; 0)$ & $0(0 ; 0)$ & $0(0 ; 0)$ \\
\hline Heterorhabdus spp. & $\begin{array}{l}10.23 \\
(4.55 ; 18.18)\end{array}$ & $\begin{array}{l}20.45 \\
(18.18 ; 22.73)\end{array}$ & $\begin{array}{l}222.73 \\
(0 ; 1027.27)\end{array}$ & $\begin{array}{l}40.91 \\
(9.09 ; 109.09)\end{array}$ & $\begin{array}{l}340.91 \\
(59.09 ; 577.27)\end{array}$ & $\begin{array}{l}131.82 \\
(77.27 ; 213.64)\end{array}$ & $\begin{array}{l}229.55 \\
(36.36 ; 463.64)\end{array}$ & $\begin{array}{l}196.59 \\
(50 ; 336.36)\end{array}$ \\
\hline Lucicutia flavicornis & $0(0 ; 0)$ & $0(0 ; 0)$ & $0(0 ; 0)$ & $0.6(0 ; 4.5)$ & $0(0 ; 0)$ & $0(0 ; 0)$ & $0(0 ; 0)$ & $0(0 ; 0)$ \\
\hline Lucicutia gemina & $0(0 ; 0)$ & $0(0 ; 0)$ & $0(0 ; 0)$ & $1.9(0 ; 13.6)$ & $0(0 ; 0)$ & $1.1(0 ; 4.5)$ & $0(0 ; 0)$ & $0(0 ; 0)$ \\
\hline Lucicutia spp. & $0(0 ; 0)$ & $9.1(0 ; 18.2)$ & $0(0 ; 0)$ & $5.8(0 ; 40.9)$ & $3.6(0 ; 18.2)$ & $5.7(0 ; 18.2)$ & $2.3(0 ; 9.1)$ & $2.3(0 ; 9.1)$ \\
\hline Mesocalanus tenuicornis & $13.6(4.5 ; 36.4)$ & $9.1(0 ; 18.2)$ & $45.5(0 ; 195.5)$ & $\begin{array}{l}69.5 \\
(9.1 ; 227.3)\end{array}$ & $1.8(0 ; 4.5)$ & $5.7(0 ; 13.6)$ & $2.3(0 ; 9.1)$ & $3.4(0 ; 9.1)$ \\
\hline Microcalanus pusilus & $0(0 ; 0)$ & $9.1(0 ; 18.2)$ & $3.6(0 ; 18.2)$ & $35.1(0 ; 227.3)$ & $15.5(0 ; 54.5)$ & $22.7(0 ; 54.5)$ & $13.6(0 ; 36.4)$ & $0(0 ; 0)$ \\
\hline Microsetella rosea & $0(0 ; 0)$ & $0(0 ; 0)$ & $0(0 ; 0)$ & $19.5(0 ; 136.4)$ & $0(0 ; 0)$ & $0(0 ; 0)$ & $0(0 ; 0)$ & $0(0 ; 0)$ \\
\hline Microsetella spp. & $\begin{array}{l}36.4 \\
(18.2 ; 54.5)\end{array}$ & $9.1(9.1 ; 9.1)$ & $14.5(0 ; 36.4)$ & $46.1(0 ; 90.9)$ & $11.8(0 ; 18.2)$ & $5.7(0 ; 13.6)$ & $36.4(0 ; 54.5)$ & $36.4(0 ; 54.5)$ \\
\hline Mimocalanus cultifer & $2.3(0 ; 9.1)$ & $4.5(0 ; 9.1)$ & $0(0 ; 0)$ & $2.6(0 ; 13.6)$ & $3.6(0 ; 18.2)$ & $29.5(0 ; 100)$ & $0(0 ; 0)$ & $14.8(4.5 ; 27.3)$ \\
\hline Miracia efferata & $5.7(0 ; 18.2)$ & $0(0 ; 0)$ & $3.6(0 ; 13.6)$ & $0(0 ; 0)$ & $0(0 ; 0)$ & $0(0 ; 0)$ & $5.7(0 ; 9.1)$ & $0(0 ; 0)$ \\
\hline Miracia minor & $0(0 ; 0)$ & $0(0 ; 0)$ & $0.9(0 ; 4.5)$ & $3.9(0 ; 18.2)$ & $0(0 ; 0)$ & $2.3(0 ; 9.1)$ & $0(0 ; 0)$ & $0(0 ; 0)$ \\
\hline Mormonilla minor & $0(0 ; 0)$ & $0(0 ; 0)$ & $46.4(0 ; 200)$ & $0(0 ; 0)$ & $30.9(9.1 ; 54.5)$ & $\begin{array}{l}72.7 \\
(36.4 ; 113.6)\end{array}$ & $52.3(0 ; 90.9)$ & $77.3(0 ; 181.8)$ \\
\hline Nannocalanus minor & $\begin{array}{l}70.5 \\
(22.7 ; 95.5)\end{array}$ & $\begin{array}{l}93.2 \\
(31.8 ; 154.5)\end{array}$ & $\begin{array}{l}150 \\
(9.1 ; 259.1)\end{array}$ & $\begin{array}{l}100.6 \\
(9.1 ; 236.4)\end{array}$ & $8.2(0 ; 18.2)$ & $20.5(9.1 ; 36.4)$ & $11.4(0 ; 27.3)$ & $14.8(4.5 ; 18.2)$ \\
\hline Neocalanus gracilis & $\begin{array}{l}252.3 \\
(118.2 ; 354.5)\end{array}$ & $\begin{array}{l}115.9 \\
(100 ; 131.8)\end{array}$ & $\begin{array}{l}850.9 \\
(263.6 ; 1413.6)\end{array}$ & $\begin{array}{l}687 \\
(450 ; 1127.3)\end{array}$ & $\begin{array}{l}500.9 \\
(318.2 ; 631.8)\end{array}$ & $\begin{array}{l}450 \\
(290.9 ; 600)\end{array}$ & $\begin{array}{l}569.3 \\
(459.1 ; 659.1)\end{array}$ & $\begin{array}{l}865.9 \\
(740.9 ; 1054.5)\end{array}$ \\
\hline
\end{tabular}


Table A1. Continued.

\begin{tabular}{|c|c|c|c|c|c|c|c|c|}
\hline \multirow[t]{2}{*}{ Copepods WP-II (ind.m ${ }^{-2}$ ) } & \multicolumn{2}{|c|}{ Part 1} & \multicolumn{2}{|c|}{ Part 2} & \multicolumn{2}{|c|}{ Part 3} & \multicolumn{2}{|c|}{ Part 4} \\
\hline & Day & Night & Day & Night & Day & Night & Day & Night \\
\hline & $N=4$ & $N=2$ & $N=5$ & $N=7$ & $N=5$ & $N=4$ & $N=4$ & $N=4$ \\
\hline Oithona similis & $\begin{array}{l}2288.6 \\
(1772.7 ; 3636.4)\end{array}$ & $\begin{array}{l}829.5 \\
(409.1 ; 1250)\end{array}$ & $\begin{array}{l}2010.9 \\
(1363.6 ; 3954.5)\end{array}$ & $\begin{array}{l}2289 \\
(909.1 ; 5227.3)\end{array}$ & $\begin{array}{l}2809.1 \\
(1590.9 ; 3750)\end{array}$ & $\begin{array}{l}1488.6 \\
(1090.9 ; 2386.4)\end{array}$ & $\begin{array}{l}2340.9 \\
(1181.8 ; 3068.2)\end{array}$ & $\begin{array}{l}1971.6 \\
(409.1 ; 3090.9)\end{array}$ \\
\hline Oithona spp. & $\begin{array}{l}719.32 \\
(9.1 ; 1363.6)\end{array}$ & $\begin{array}{l}279.55 \\
(250 ; 309.1)\end{array}$ & $\begin{array}{l}2183.64 \\
(204.5 ; 4954.5)\end{array}$ & $\begin{array}{l}1703.25 \\
(300 ; 4518.2)\end{array}$ & $\begin{array}{l}1892.73 \\
(981.8 ; 3813.6)\end{array}$ & $\begin{array}{l}1212.50 \\
(554.6 ; 1768.2)\end{array}$ & $\begin{array}{l}992.05 \\
(200 ; 1490.9)\end{array}$ & $\begin{array}{l}722.73 \\
(609.1 ; 890.9)\end{array}$ \\
\hline Oncaea mediterranea & $0(0 ; 0)$ & $0(0 ; 0)$ & $0.9(0 ; 4.5)$ & $1.3(0 ; 4.5)$ & $0(0 ; 0)$ & $0(0 ; 0)$ & $0(0 ; 0)$ & $0(0 ; 0)$ \\
\hline Oncaea spp. & $4.5(0 ; 18.2)$ & $0(0 ; 0)$ & $74.5(0 ; 236.4)$ & $46.1(0 ; 113.6)$ & $34.5(0 ; 136.4)$ & $15.9(0 ; 27.3)$ & $36.4(0 ; 90.9)$ & $0(0 ; 0)$ \\
\hline Paracalanus nanus & $11.4(0 ; 36.4)$ & $0(0 ; 0)$ & $0(0 ; 0)$ & $7.8(0 ; 36.4)$ & $0(0 ; 0)$ & $0(0 ; 0)$ & $4.5(0 ; 18.2)$ & $0(0 ; 0)$ \\
\hline Paracalanus spp. & $0(0 ; 0)$ & $0(0 ; 0)$ & $0(0 ; 0)$ & $0(0 ; 0)$ & $3.6(0 ; 18.2)$ & $5.7(0 ; 18.2)$ & $0(0 ; 0)$ & $0(0 ; 0)$ \\
\hline Pareuchaeta spinosa & $0(0 ; 0)$ & $0(0 ; 0)$ & $0(0 ; 0)$ & $1.3(0 ; 9.1)$ & $0(0 ; 0)$ & $0(0 ; 0)$ & $0(0 ; 0)$ & $0(0 ; 0)$ \\
\hline Paroithona parvula & $0(0 ; 0)$ & $0(0 ; 0)$ & $0(0 ; 0)$ & $13(0 ; 72.7)$ & $7.3(0 ; 18.2)$ & $1.1(0 ; 4.5)$ & $4.5(0 ; 18.2)$ & $27.3(0 ; 90.9)$ \\
\hline Pleuromamma abdominalis & $1.1(0 ; 4.5)$ & $\begin{array}{l}31.8 \\
(27.3 ; 36.4)\end{array}$ & $21.8(0 ; 90.9)$ & $\begin{array}{l}68.2 \\
(4.5 ; 113.6)\end{array}$ & $30.9(0 ; 100)$ & $46.6(4.5 ; 86.4)$ & $4.5(0 ; 18.2)$ & $\begin{array}{l}45.5 \\
(18.2 ; 63.6)\end{array}$ \\
\hline Pleuromamma gracilis & $1.1(0 ; 4.5)$ & $\begin{array}{l}56.8 \\
(40.9 ; 72.7)\end{array}$ & $\begin{array}{l}648.2 \\
(0 ; 1845.5)\end{array}$ & $\begin{array}{l}714.3 \\
(22.7 ; 1913.6)\end{array}$ & $\begin{array}{l}1758.2 \\
(595.5 ; 2495.5)\end{array}$ & $\begin{array}{l}1568.2 \\
(350 ; 3322.7)\end{array}$ & $\begin{array}{l}647.7 \\
(218.2 ; 1354.5)\end{array}$ & $\begin{array}{l}725 \\
(386.4 ; 1086.4)\end{array}$ \\
\hline Ratania flava & $0(0 ; 0)$ & $0(0 ; 0)$ & $1.8(0 ; 9.1)$ & $7.8(0 ; 27.3)$ & $6.4(0 ; 18.2)$ & $3.4(0 ; 4.5)$ & $0(0 ; 0)$ & $3.4(0 ; 9.1)$ \\
\hline Scaphocalanus curtus & $4.5(0 ; 18.2)$ & $13.6(9.1 ; 18.2)$ & $14.5(0 ; 36.4)$ & $61(0 ; 136.4)$ & $\begin{array}{l}40 \\
(18.2 ; 109.1)\end{array}$ & $\begin{array}{l}59.1 \\
(54.5 ; 72.7)\end{array}$ & $6.8(0 ; 18.2)$ & $54.5(0 ; 72.7)$ \\
\hline Scolecithricella spp. & $4.55(0 ; 9.09)$ & $\begin{array}{l}38.64 \\
(27.27 ; 50)\end{array}$ & $10(0 ; 22.73)$ & $\begin{array}{l}143.51 \\
(40.91 ; 245.45)\end{array}$ & $\begin{array}{l}42.73 \\
(9.09 ; 109.09)\end{array}$ & $\begin{array}{l}130.68 \\
(86.36 ; 209.09)\end{array}$ & $\begin{array}{l}15.91 \\
(0 ; 45.45)\end{array}$ & $\begin{array}{l}88.64 \\
(45.45 ; 163.64)\end{array}$ \\
\hline Scolecithrix bradyi & $0(0 ; 0)$ & $0(0 ; 0)$ & $0(0 ; 0)$ & $0.6(0 ; 4.5)$ & $0(0 ; 0)$ & $0(0 ; 0)$ & $0(0 ; 0)$ & $0(0 ; 0)$ \\
\hline Scolecithrix danae & $0(0 ; 0)$ & $0(0 ; 0)$ & $0(0 ; 0)$ & $0(0 ; 0)$ & $0(0 ; 0)$ & $0(0 ; 0)$ & $1.1(0 ; 4.5)$ & $0(0 ; 0)$ \\
\hline Spinocalanus spp. & $0(0 ; 0)$ & $13.6(9.1 ; 18.2)$ & $0(0 ; 0)$ & $7.8(0 ; 36.4)$ & $4.5(0 ; 18.2)$ & $4.5(0 ; 18.2)$ & $4.5(0 ; 18.2)$ & $9.1(0 ; 36.4)$ \\
\hline Vettoria granulosa & $\begin{array}{l}50 \\
(18.2 ; 118.2)\end{array}$ & $50(27.3 ; 72.7)$ & $\begin{array}{l}105.5 \\
(27.3 ; 272.7)\end{array}$ & $48.1(9.1 ; 81.8)$ & $14.5(0 ; 27.3)$ & $18.2(9.1 ; 27.3)$ & $\begin{array}{l}43.2 \\
(27.3 ; 72.7)\end{array}$ & $\begin{array}{l}40.9 \\
(27.3 ; 54.5)\end{array}$ \\
\hline
\end{tabular}

Table A2. List of non-copepod taxa sampled with WP-II net (200 $\mu \mathrm{m}$ mesh-size) during DYNAPROC 2 cruise. Parts 1 to 4 are the time sequences defined in paragraph 3.3.3. $N$ is the number of samples. Abundances are expressed in number of individuals per meter square integrating through the layer 0-200 m: average (min;max).

\begin{tabular}{|c|c|c|c|c|c|c|c|c|}
\hline \multirow[t]{2}{*}{ Non-copepod WP-II (ind.m ${ }^{-2}$ ) } & \multicolumn{2}{|c|}{ Part 1} & \multicolumn{2}{|c|}{ Part 2} & \multicolumn{2}{|c|}{ Part 3} & \multicolumn{2}{|c|}{ Part 4} \\
\hline & Day & Night & Day & Night & Day & Night & Day & Night \\
\hline & $N=4$ & $N=2$ & $N=5$ & $N=7$ & $N=5$ & $N=4$ & $N=4$ & $N=4$ \\
\hline Appendicularians & $0(0 ; 0)$ & $0(0 ; 0)$ & $\begin{array}{l}479.1 \\
(0 ; 1827.3)\end{array}$ & $\begin{array}{l}805.2 \\
(0 ; 3954.5)\end{array}$ & $\begin{array}{l}519.1 \\
(0 ; 1022.7)\end{array}$ & $\begin{array}{l}520.5 \\
(18.2 ; 1159.1)\end{array}$ & $\begin{array}{l}380.7 \\
(0 ; 636.4)\end{array}$ & $272.7(0 ; 1000)$ \\
\hline Chaetognaths & $4.5(0 ; 9.1)$ & $0(0 ; 0)$ & $\begin{array}{l}43.6 \\
(4.5 ; 181.8)\end{array}$ & $15.6(4.5 ; 31.8)$ & $14.5(0 ; 36.4)$ & $6.8(0 ; 18.2)$ & $\begin{array}{l}21.6 \\
(13.6 ; 31.8)\end{array}$ & $11.4(0 ; 31.8)$ \\
\hline Doliolids & $0(0 ; 0)$ & $0(0 ; 0)$ & $0.9(0 ; 4.5)$ & $3.2(0 ; 22.7)$ & $0(0 ; 0)$ & $0(0 ; 0)$ & $0(0 ; 0)$ & $1.1(0 ; 4.5)$ \\
\hline Euphausiids & $8(0 ; 18.2)$ & $11.4(4.5 ; 18.2)$ & $10.9(9.1 ; 13.6)$ & $\begin{array}{l}21.4 \\
(13.6 ; 27.3)\end{array}$ & $6.4(0 ; 18.2)$ & $11.4(4.5 ; 22.7)$ & $8(4.5 ; 9.1)$ & $\begin{array}{l}36.4 \\
(13.6 ; 63.6)\end{array}$ \\
\hline Fishes & $1.1(0 ; 4.5)$ & $0(0 ; 0)$ & $2.7(0 ; 13.6)$ & $4.5(0 ; 27.3)$ & $5.5(0 ; 9.1)$ & $5.7(0 ; 13.6)$ & $3.4(0 ; 4.5)$ & $0(0 ; 0)$ \\
\hline Hydromedusae & $0(0 ; 0)$ & $0(0 ; 0)$ & $0(0 ; 0)$ & $7.8(0 ; 27.3)$ & $1.8(0 ; 9.1)$ & $5.7(0 ; 13.6)$ & $10.2(0 ; 36.4)$ & $1.1(0 ; 4.5)$ \\
\hline Hyperiids & $8(0 ; 22.7)$ & $\begin{array}{l}136.4 \\
(68.2 ; 204.5)\end{array}$ & $1.8(0 ; 4.5)$ & $26(0 ; 50)$ & $8.2(0 ; 40.9)$ & $21.6(0 ; 40.9)$ & $2.3(0 ; 9.1)$ & $25(9.1 ; 40.9)$ \\
\hline Isopods & $5.7(0 ; 13.6)$ & $2.3(0 ; 4.5)$ & $17.3(9.1 ; 27.3)$ & $11.7(0 ; 36.4)$ & $5.5(0 ; 13.6)$ & $9.1(0 ; 13.6)$ & $1.1(0 ; 4.5)$ & $9.1(9.1 ; 9.1)$ \\
\hline Mysidacea & $0(0 ; 0)$ & $0(0 ; 0)$ & $0(0 ; 0)$ & $0(0 ; 0)$ & $0(0 ; 0)$ & $0(0 ; 0)$ & $1.1(0 ; 4.5)$ & $0(0 ; 0)$ \\
\hline Ostracods & $1.1(0 ; 4.5)$ & $4.5(0 ; 9.1)$ & $\begin{array}{l}61.8 \\
(9.1 ; 145.5)\end{array}$ & $\begin{array}{l}184.4 \\
(18.2 ; 818.2)\end{array}$ & $\begin{array}{l}90 \\
(22.7 ; 245.5)\end{array}$ & $30.7(0 ; 68.2)$ & $29.5(0 ; 72.7)$ & $\begin{array}{l}31.8 \\
(18.2 ; 45.5)\end{array}$ \\
\hline Pteropods & $2.3(0 ; 9.1)$ & $\begin{array}{l}38.6 \\
(18.2 ; 59.1)\end{array}$ & $60(0 ; 236.4)$ & $50(0 ; 168.2)$ & $\begin{array}{l}172.7 \\
(63.6 ; 300)\end{array}$ & $\begin{array}{l}128.4 \\
(45.5 ; 186.4)\end{array}$ & $\begin{array}{l}187.5 \\
(72.7 ; 377.3)\end{array}$ & $150(50 ; 250)$ \\
\hline Salps & $0(0 ; 0)$ & $0(0 ; 0)$ & $0(0 ; 0)$ & $0(0 ; 0)$ & $0(0 ; 0)$ & $0(0 ; 0)$ & $1.1(0 ; 4.5)$ & $0(0 ; 0)$ \\
\hline $\begin{array}{l}\text { Siphonophora } \\
\text { destructed (parts) }\end{array}$ & - & - & - & - & - & - & - & - \\
\hline
\end{tabular}


Table A3. List of copepod species sampled with BIONESS net (500 $\mu \mathrm{m}$ mesh-size) during DYNAPROC 2 cruise. Parts 1 to 4 are the time sequences defined in paragraph 3.3.3. $N$ is the number of samples. Abundances are expressed in number of individuals per meter square integrating through the layer 0-250 m: average (min;max).

\begin{tabular}{|c|c|c|c|c|c|c|c|c|}
\hline \multirow[t]{2}{*}{ Copepods BIONESS (ind.m ${ }^{-2}$ ) } & \multicolumn{2}{|c|}{ Part 1} & \multicolumn{2}{|c|}{ Part 2} & \multicolumn{2}{|c|}{ Part 3} & \multicolumn{2}{|c|}{ Part 4} \\
\hline & Day & Night & Day & Night & Day & Night & Day & Night \\
\hline & $N=4$ & $N=3$ & $N=6$ & $N=7$ & $N=5$ & $N=6$ & $N=3$ & $N=4$ \\
\hline Acartia spp. & $0(0 ; 0)$ & $0(0 ; 0)$ & $0.03(0 ; 0.2)$ & $0(0 ; 0)$ & $0.09(0 ; 0.3)$ & $0(0 ; 0)$ & $0.08(0 ; 0.3)$ & $0(0 ; 0)$ \\
\hline Aetideus acutus & $0(0 ; 0)$ & $0.08(0 ; 0.2)$ & $0(0 ; 0)$ & $0(0 ; 0)$ & $0(0 ; 0)$ & $0(0 ; 0)$ & $0(0 ; 0)$ & $0(0 ; 0)$ \\
\hline Aetideus armatus & $0.19(0 ; 0.4)$ & $0.69(0.5 ; 0.9)$ & $0.81(0.1 ; 2.9)$ & $0.3(0 ; 1.1)$ & $0.28(0 ; 0.8)$ & $0.3(0 ; 0.7)$ & $0(0 ; 0)$ & $0(0 ; 0.1)$ \\
\hline Aetideus giesbrechti & $0.21(0 ; 0.7)$ & $0.25(0 ; 0.8)$ & $0.34(0 ; 0.9)$ & $0.2(0 ; 0.6)$ & $0.14(0.1 ; 0.2)$ & $0.3(0 ; 0.6)$ & $0.18(0.1 ; 0.2)$ & $0.3(0.09 ; 0.5)$ \\
\hline Aetideus spp. & $0.14(0 ; 0.6)$ & $0.03(0 ; 0.1)$ & $0(0 ; 0)$ & $0.2(0 ; 0.7)$ & $0(0 ; 0)$ & $0(0 ; 0)$ & $0(0 ; 0)$ & $0(0 ; 0)$ \\
\hline Arietellus minor & $0(0 ; 0)$ & $0(0 ; 0)$ & $0(0 ; 0)$ & $0(0 ; 0)$ & $0(0 ; 0)$ & $0(0 ; 0.1)$ & $0.02(0 ; 0.1)$ & $0(0 ; 0.1)$ \\
\hline Arietellus setosus & $0(0 ; 0)$ & $0.03(0 ; 0.1)$ & $0.1(0 ; 0.2)$ & $0.1(0 ; 0.3)$ & $0.08(0 ; 0.2)$ & $0(0 ; 0)$ & $0(0 ; 0)$ & $0(0 ; 0.1)$ \\
\hline Arietellus spp. & $0(0 ; 0)$ & $0(0 ; 0)$ & $0.02(0 ; 0.1)$ & $0(0 ; 0)$ & $0(0 ; 0)$ & $0(0 ; 0)$ & $0.02(0 ; 0.1)$ & $0(0 ; 0.1)$ \\
\hline Augaptilus longicaudatus & $0(0 ; 0)$ & $0(0 ; 0)$ & $0.05(0 ; 0.1)$ & $0(0 ; 0.1)$ & $0.02(0 ; 0.1)$ & $0(0 ; 0)$ & $0.1(0 ; 0.2)$ & $0(0 ; 0.2)$ \\
\hline Calanus helgolandicus & $0.96(0 ; 2.1)$ & $0.41(0 ; 0.8)$ & $0.46(0 ; 1.6)$ & $0.9(0 ; 2.3)$ & $1.59(0 ; 3.3)$ & $4.3(0.86 ; 12.6)$ & $0.83(0.1 ; 1.3)$ & $0.5(0 ; 0.9)$ \\
\hline Centropages typicus & $2.59(1.6 ; 3.5)$ & $2.25(1.7 ; 2.6)$ & $2.22(0.6 ; 7.4)$ & $1.4(0.11 ; 4.1)$ & $1.4(0.1 ; 3.1)$ & $0.4(0 ; 1.5)$ & $0.75(0.3 ; 1.1)$ & $0.3(0 ; 1)$ \\
\hline Centropages violaceus & $0.58(0 ; 1.3)$ & $0.21(0 ; 0.5)$ & $0.19(0 ; 0.7)$ & $0(0 ; 0.1)$ & $0(0 ; 0)$ & $0.4(0 ; 1.1)$ & $0.1(0 ; 0.3)$ & $0(0 ; 0)$ \\
\hline Chiridius gracilis & $0(0 ; 0)$ & $0(0 ; 0)$ & $0(0 ; 0)$ & $0(0 ; 0.1)$ & $0(0 ; 0)$ & $0(0 ; 0)$ & $0(0 ; 0)$ & $0.1(0 ; 0.1)$ \\
\hline Chiridius poppei & $2.4(0.8 ; 4.9)$ & $3.08(2.4 ; 4.1)$ & $2.84(0.8 ; 9.4)$ & $6.6(2.3 ; 17)$ & $3.2(0.8 ; 6.7)$ & $\begin{array}{l}12.5 \\
(8.24 ; 17.6)\end{array}$ & $2.93(1.5 ; 4.8)$ & $10(3.8 ; 18.2)$ \\
\hline Clausocalanus spp. & $1.16(0.2 ; 3.7)$ & $0(0 ; 0)$ & $0.94(0 ; 2)$ & $0.8(0 ; 3.7)$ & $0.57(0.2 ; 1.3)$ & $0.6(0 ; 2.7)$ & $0.19(0 ; 0.6)$ & $0(0 ; 0)$ \\
\hline Corycaeus furcifer & $0.03(0 ; 0.1)$ & $0(0 ; 0)$ & $0.29(0 ; 1.3)$ & $0(0 ; 0)$ & $0.15(0 ; 0.3)$ & $0(0 ; 0.1)$ & $0.24(0 ; 0.7)$ & $0(0 ; 0)$ \\
\hline Corycaeus typicus & $0(0 ; 0)$ & $0(0 ; 0)$ & $0.02(0 ; 0.1)$ & $0(0 ; 0)$ & $0.02(0 ; 0.1)$ & $0(0 ; 0)$ & $0(0 ; 0)$ & $0(0 ; 0.1)$ \\
\hline Eucalanus hyalinus & $0.29(0 ; 0.8)$ & $0.04(0 ; 0.1)$ & $0.28(0 ; 0.7)$ & $0.1(0 ; 0.4)$ & $0.28(0 ; 0.5)$ & $0.3(0 ; 0.8)$ & $0.14(0 ; 0.3)$ & $0.2(0 ; 0.5)$ \\
\hline Euchaeta spp. & $\begin{array}{l}23.98 \\
(9.3 ; 41.9)\end{array}$ & $\begin{array}{l}58.72 \\
(44.6 ; 70.5)\end{array}$ & $\begin{array}{l}89.93 \\
(6.8 ; 176.6)\end{array}$ & $\begin{array}{l}123.9 \\
(76.24 ; 164.9)\end{array}$ & $\begin{array}{l}33.79 \\
(7.9 ; 54.4)\end{array}$ & $\begin{array}{l}100.4 \\
(50.17 ; 127.9)\end{array}$ & $\begin{array}{l}39.14 \\
(2.9 ; 99.1)\end{array}$ & $\begin{array}{l}95.9 \\
(82.51 ; 120.1)\end{array}$ \\
\hline Euchirella messinensis & $0.2(0.1 ; 0.4)$ & $5.93(5.1 ; 7.6)$ & $0.5(0 ; 1.3)$ & $7.5(4.47 ; 11.8)$ & $0.33(0 ; 1.2)$ & $6.8(4.07 ; 14.4)$ & $0.03(0 ; 0.1)$ & $4.6(3.31 ; 5.8)$ \\
\hline Gaetanus kruppi & $0(0 ; 0)$ & $0(0 ; 0)$ & $0.09(0 ; 0.4)$ & $0(0 ; 0.2)$ & $0.11(0 ; 0.4)$ & $0.1(0 ; 0.4)$ & $0.07(0 ; 0.2)$ & $0.2(0 ; 0.3)$ \\
\hline Haloptilus acutifrons & $0.24(0.1 ; 0.4)$ & $0.1(0 ; 0.2)$ & $0.35(0 ; 0.8)$ & $0.5(0 ; 1.5)$ & $0.3(0.1 ; 0.4)$ & $0.1(0 ; 0.2)$ & $0.54(0.4 ; 0.6)$ & $0.2(0 ; 0.3)$ \\
\hline Haloptilus longicornis & $1.43(1.1 ; 1.8)$ & $0.32(0.3 ; 0.4)$ & $4.08(0.4 ; 8.4)$ & $3.1(0.13 ; 7.8)$ & $3.1(2.1 ; 4.7)$ & $0.8(0 ; 2.5)$ & $2.73(2 ; 3.8)$ & $1.4(0.1 ; 2.8)$ \\
\hline Haloptilus spp. & $0(0 ; 0)$ & $0(0 ; 0)$ & $0.04(0 ; 0.2)$ & $0(0 ; 0)$ & $0(0 ; 0)$ & $0(0 ; 0)$ & $0(0 ; 0)$ & $0(0 ; 0.2)$ \\
\hline Heterorhabdus spp. & $\begin{array}{l}17.68 \\
(13.8 ; 19.6)\end{array}$ & $\begin{array}{l}11.28 \\
(9.9 ; 12.6)\end{array}$ & $\begin{array}{l}32.99 \\
(14 ; 45.7)\end{array}$ & $\begin{array}{l}19.6 \\
(9.31 ; 50.5)\end{array}$ & $\begin{array}{l}13.84 \\
(10.6 ; 16.7)\end{array}$ & $\begin{array}{l}11.1 \\
(7.25 ; 16.5)\end{array}$ & $\begin{array}{l}16.47 \\
(8.2 ; 23.9)\end{array}$ & $\begin{array}{l}14.7 \\
(8.78 ; 21.9)\end{array}$ \\
\hline Labidocera acuta & $0.03(0 ; 0.1)$ & $0(0 ; 0)$ & $0(0 ; 0)$ & $0(0 ; 0)$ & $0(0 ; 0)$ & $0(0 ; 0)$ & $0(0 ; 0)$ & $0(0 ; 0)$ \\
\hline Lucicutia curta & $0.08(0 ; 0.3)$ & $0(0 ; 0)$ & $0(0 ; 0)$ & $0(0 ; 0.3)$ & $0(0 ; 0)$ & $0.1(0 ; 0.3)$ & $0.05(0 ; 0.2)$ & $0(0 ; 0)$ \\
\hline Lucicutia gemina & $0(0 ; 0)$ & $0(0 ; 0)$ & $0(0 ; 0)$ & $0(0 ; 0.2)$ & $0(0 ; 0)$ & $0(0 ; 0.1)$ & $0(0 ; 0)$ & $0(0 ; 0)$ \\
\hline Lucicutia spp. & $0(0 ; 0)$ & $0(0 ; 0)$ & $0.09(0 ; 0.6)$ & $0(0 ; 0)$ & $0(0 ; 0)$ & $0(0 ; 0)$ & $0(0 ; 0)$ & $0(0 ; 0)$ \\
\hline Mesocalanus tenuicornis & $5.25(1.8 ; 14.4)$ & $4.62(2.5 ; 6.4)$ & $16.27(4.4 ; 38)$ & $\begin{array}{l}18.9 \\
(1.95 ; 49.5)\end{array}$ & $4.61(3 ; 6.8)$ & $6.6(2.74 ; 14.1)$ & $1.75(0.4 ; 3)$ & $1.2(0.55 ; 2.1)$ \\
\hline Monacilla typica & $0.07(0 ; 0.2)$ & $0(0 ; 0)$ & $0.13(0 ; 0.4)$ & $0.3(0 ; 1)$ & $0.17(0 ; 0.3)$ & $0.3(0 ; 0.7)$ & $0.1(0 ; 0.2)$ & $0.1(0 ; 0.5)$ \\
\hline Nannocalanus minor & $\begin{array}{l}88.31 \\
(43.3 ; 135.1)\end{array}$ & $\begin{array}{l}66.61 \\
(40.9 ; 87.7)\end{array}$ & $\begin{array}{l}116.28 \\
(9.2 ; 542.9)\end{array}$ & $\begin{array}{l}79 \\
(0.17 ; 321.9)\end{array}$ & $\begin{array}{l}11.59 \\
(5.3 ; 17.5)\end{array}$ & $8.9(1.37 ; 14.3)$ & $\begin{array}{l}10.57 \\
(8.6 ; 12.3)\end{array}$ & $5.1(2.05 ; 11.7)$ \\
\hline Neocalanus gracilis & $\begin{array}{l}164.74 \\
(70.5 ; 321.8)\end{array}$ & $86.3(0 ; 146.9)$ & $\begin{array}{l}693.56 \\
(52.1 ; 2241)\end{array}$ & $\begin{array}{l}588.6 \\
(89.89 ; 1357.5)\end{array}$ & $\begin{array}{l}198.91 \\
(147.8 ; 316.7)\end{array}$ & $\begin{array}{l}153.7 \\
(112.77 ; 245.4)\end{array}$ & $\begin{array}{l}205.88 \\
(126 ; 357.7)\end{array}$ & $\begin{array}{l}195.6 \\
(124.52 ; 308.9)\end{array}$ \\
\hline Paracandacia simplex & $0.03(0 ; 0.1)$ & $0(0 ; 0)$ & $0.2(0 ; 1.2)$ & $0(0 ; 0)$ & $0(0 ; 0)$ & $0(0 ; 0.1)$ & $0.04(0 ; 0.1)$ & $0.1(0 ; 0.3)$ \\
\hline Pleuromamma abdominalis & $0.48(0 ; 1.3)$ & $\begin{array}{l}24.81 \\
(19.4 ; 27.9)\end{array}$ & $4.01(0.1 ; 11)$ & $\begin{array}{l}41.1 \\
(19.81 ; 61.7)\end{array}$ & $0.54(0.2 ; 1.7)$ & $\begin{array}{l}20.1 \\
(9.45 ; 42.1)\end{array}$ & $0.5(0 ; 1.1)$ & $\begin{array}{l}35.1 \\
(15.65 ; 81.2)\end{array}$ \\
\hline Pleuromamma gracilis & $2.41(0.4 ; 5.6)$ & $\begin{array}{l}34.98 \\
(21.9 ; 54.3)\end{array}$ & $21.39(0.2 ; 54)$ & $\begin{array}{l}104.5 \\
(16.46 ; 356.5)\end{array}$ & $1.84(0 ; 5.6)$ & $\begin{array}{l}35.8 \\
(21.41 ; 53.5)\end{array}$ & $5.78(0.6 ; 16.2)$ & $\begin{array}{l}42.4 \\
(37.44 ; 46.9)\end{array}$ \\
\hline Ratania flava & $0(0 ; 0)$ & $0(0 ; 0)$ & $0.02(0 ; 0.1)$ & $0(0 ; 0)$ & $0.06(0 ; 0.3)$ & $0(0 ; 0.1)$ & $0(0 ; 0)$ & $0(0 ; 0)$ \\
\hline Rhincalanus nasutus & $0(0 ; 0)$ & $0(0 ; 0)$ & $0(0 ; 0)$ & $0(0 ; 0.1)$ & $0.03(0 ; 0.1)$ & $0(0 ; 0.1)$ & $0(0 ; 0)$ & $0(0 ; 0)$ \\
\hline Sapphirina spp. & $0(0 ; 0)$ & $0(0 ; 0)$ & $0.05(0 ; 0.3)$ & $0(0 ; 0)$ & $0(0 ; 0)$ & $0(0 ; 0)$ & $0(0 ; 0)$ & $0(0 ; 0)$ \\
\hline Scolecithricella spp. & $\begin{array}{l}15.61 \\
(13.5 ; 17.9)\end{array}$ & $\begin{array}{l}18.97 \\
(10.8 ; 33.7)\end{array}$ & $\begin{array}{l}27.38 \\
(8.5 ; 55.1)\end{array}$ & $\begin{array}{l}40.3 \\
(15.99 ; 55.3)\end{array}$ & $\begin{array}{l}26.95 \\
(19.7 ; 35)\end{array}$ & $\begin{array}{l}33.1 \\
(16.87 ; 42.3)\end{array}$ & $19.27(8 ; 32.5)$ & $\begin{array}{l}24.6 \\
(6.61 ; 47.1)\end{array}$ \\
\hline Scolecithrix bradyi & $0(0 ; 0)$ & $0(0 ; 0)$ & $0(0 ; 0)$ & $0(0 ; 0.1)$ & $0.02(0 ; 0.1)$ & $0(0 ; 0)$ & $0(0 ; 0)$ & $0(0 ; 0)$ \\
\hline Scolecithrix danae & $0.16(0 ; 0.6)$ & $0(0 ; 0)$ & $0(0 ; 0)$ & $0(0 ; 0)$ & $0(0 ; 0)$ & $0(0 ; 0)$ & $0(0 ; 0)$ & $0(0 ; 0)$ \\
\hline
\end{tabular}


Table A4. List of non-copepod taxa sampled with BIONESS net (500 $\mu \mathrm{m}$ mesh-size) during DYNAPROC 2 cruise. Parts 1 to 4 are the time sequences defined in paragraph 3.3.3. $N$ is the number of samples. Abundances are expressed in number of individuals per meter square integrating through the layer 0-250 m: average (min;max).

\begin{tabular}{|c|c|c|c|c|c|c|c|c|}
\hline \multirow[t]{2}{*}{ Non-copepod BIONESS (ind.m-2) } & \multicolumn{2}{|c|}{ Part 1} & \multicolumn{2}{|c|}{ Part 2} & \multicolumn{2}{|c|}{ Part 3} & \multicolumn{2}{|c|}{ Part 4} \\
\hline & Day & Night & Day & Night & Day & Night & Day & Night \\
\hline & $N=4$ & $N=3$ & $N=6$ & $N=7$ & $N=5$ & $N=6$ & $N=3$ & $N=4$ \\
\hline Chaetognaths & $\begin{array}{l}18.3 \\
(14.2 ; 21.3)\end{array}$ & $7.45(3.7 ; 12.2)$ & $18.9(9.8 ; 42.6)$ & $\begin{array}{l}18.53 \\
(4.2 ; 36.6)\end{array}$ & $14.53(8.4 ; 20)$ & $9.1(5.5 ; 14.3)$ & $\begin{array}{l}11.66 \\
(8.1 ; 16.8)\end{array}$ & $8.36(4.9 ; 12.2)$ \\
\hline Decapods & $0.32(0 ; 1.2)$ & $3.46(1.6 ; 4.4)$ & $0.17(0 ; 0.4)$ & $2.84(0.7 ; 6.6)$ & $0.09(0 ; 0.4)$ & $1.62(0 ; 2.6)$ & $0(0 ; 0$ & $4.17(3.3 ; 6.6)$ \\
\hline Doliolids & $0.53(0.1 ; 0.9)$ & $0.27(0 ; 0.5)$ & $0.81(0.2 ; 2)$ & $0.52(0 ; 1.5)$ & $0.55(0 ; 1.5)$ & $0.32(0.1 ; 0.7)$ & $0.28(0.2 ; 0.3)$ & $0.47(0 ; 0.8)$ \\
\hline Euphausiids & $10.1(6.4 ; 12.7)$ & $\begin{array}{l}88.37 \\
(71.1 ; 119)\end{array}$ & $\begin{array}{l}11.34 \\
(9.3 ; 13.8)\end{array}$ & $\begin{array}{l}115.68 \\
(43.5 ; 178.9)\end{array}$ & $7.93(6.6 ; 10.2)$ & $\begin{array}{l}96.81 \\
(35.4 ; 209.3)\end{array}$ & $11.14(7.4 ; 18.3$ & $\begin{array}{l}71.88 \\
(23.5 ; 95.1)\end{array}$ \\
\hline Fishes & $0.33(0.1 ; 0.6)$ & $0.89(0 ; 1.4)$ & $0.86(0 ; 2.1)$ & $0.86(0 ; 1.9)$ & $0.73(0 ; 3.1)$ & $4.78(0 ; 20.3)$ & $0.65(0 ; 1$ & $1.21(0 ; 2.9)$ \\
\hline Gymnosoms & $0(0 ; 0)$ & $0(0 ; 0)$ & $0.03(0 ; 0.2)$ & $0(0 ; 0)$ & $0.04(0 ; 0.2)$ & $0.05(0 ; 0.2)$ & $0(0 ; 0$ & $0(0 ; 0)$ \\
\hline Hydromedusae & $0.16(0 ; 0.6)$ & $0.17(0 ; 0.4)$ & $0.43(0 ; 1.8)$ & $2.94(0.2 ; 6.9)$ & $0.04(0 ; 0.1)$ & $2.45(0 ; 9.7)$ & $0.3(0 ; 0.7$ & $2.28(0.9 ; 3.7)$ \\
\hline Hyperiids & $1.94(0.5 ; 3.2)$ & $\begin{array}{l}24.19 \\
(12.6 ; 30.1)\end{array}$ & $1.29(0.6 ; 1.9)$ & $\begin{array}{l}13.74 \\
(4.4 ; 20.9)\end{array}$ & $1.1(0.5 ; 1.4)$ & $\begin{array}{l}14.49 \\
(8.7 ; 23.6)\end{array}$ & $2.17(0.8 ; 4.5)$ & $\begin{array}{l}17.99 \\
(8.5 ; 24.4)\end{array}$ \\
\hline Mysiids & $0.14(0.1 ; 0.3)$ & $0(0 ; 0)$ & $0.05(0 ; 0.1)$ & $0.04(0 ; 0.1)$ & $0.04(0 ; 0.1)$ & $0.1(0 ; 0.4)$ & $0(0 ; 0)$ & $0.07(0 ; 0.3)$ \\
\hline Ostracods & $1.26(0.5 ; 2.3)$ & $0.31(0 ; 0.5)$ & $9.95(0 ; 37.1)$ & $0.88(0 ; 2.3)$ & $1.64(0 ; 5.1)$ & $0.94(0 ; 4.1)$ & $2.09(0 ; 5.4)$ & $0.55(0 ; 1.9)$ \\
\hline Polychaets & $0.73(0.3 ; 1.8)$ & $0.33(0.1 ; 0.6)$ & $1.72(0.1 ; 7.4)$ & $0.9(0.4 ; 1.4)$ & $2.63(0.2 ; 5.9)$ & $1.08(0 ; 4.3)$ & $2.79(0.5 ; 7.3)$ & $0.34(0 ; 1)$ \\
\hline Pteropods & $2.56(0.2 ; 5.8)$ & $19(13.3 ; 24.7)$ & $6.96(0.5 ; 16)$ & $\begin{array}{l}19.69 \\
(4.1 ; 43.3)\end{array}$ & $\begin{array}{l}10.85 \\
(1.9 ; 15.1)\end{array}$ & $\begin{array}{l}25.38 \\
(13 ; 42.7)\end{array}$ & $6.2(0.3 ; 11.5)$ & $\begin{array}{l}13.17 \\
(7.5 ; 17.5)\end{array}$ \\
\hline Siphonophora destructed (parts) & - & - & - & - & - & - & - & - \\
\hline
\end{tabular}

Acknowledgements. This study was part of the PECHE project; financial support was provided by the INSU-CNRS through the PROOF program (JGOFS-France). We thank the chief scientist, $\mathrm{V}$. Andersen, for organising the DYNAPROC 2 cruise program, and the crew of the R/V Thalassa for ship operations. We thank J. Dolan for English corrections and anonymous referees for helpful comments. This paper is dedicated to our friend and colleague Valérie Andersen who prematurely passed away in March 2007.

Edited by: A. Boetius

\section{References}

Al-Mutairi, H. and Landry, M. R.: Active export of carbon and nitrogen at Station ALOHA by diel migrant zooplankton, DeepSea Res. Pt. II, 48, 2083-2103, 2001.

Andersen, V. and Prieur, L.: One-month study in the open NW Mediterranean Sea (DYNAPROC experiment, May 1995): Overview of the hydrobiogeochemical structures and effects of wind events, Deep-Sea Res. Pt. I, 47, 397-422, 2000.

Andersen, V., Nival, P., Caparroy, P., and Gubanova, A.: Zooplankton community during the transition from spring bloom to oligotrophy in the open NW Mediterranean and effects of wind events, 1. Abundance and specific composition, J. Plankton Res., 23(3), 227-242, 2001a.

Andersen, V., Gubanova, A., Nival, P., and Ruellet T.: Zooplankton community during the transition from spring bloom to oligotrophy in the open NW Mediterranean and effects of wind events, 2. Vertical distributions and migrations, J. Plankton Res., 23(3), 243-261, 2001b.

Andersen, V., Goutx, M., Prieur, L., and Dolan, J. R.: Short-scale temporal variability of physical, biological and biogeochemical processes in the NW Mediterranean Sea: an introduction, Biogeosciences Discuss., accepted, 2008.
Beaugrand, G., Ibañez, F., Lindley, J. A., and Reid, P. C.: Diversity of calanoid copepods in the North Atlantic and adjacent seas: species associations and biogeography, Mar. Ecol. Prog. Ser., 232, 179-195, 2002.

Béthoux, J.-P. and Prieur, L.: Hydrologie et circulation en Méditerranée Nord-Occidentale, Pétroles et Techniques, 299, 25-34, 1983.

Bonnet, S., Richardson, A., Harris, R. P., Hirst, A., Beaugrand, G., Edwards, M., Ceballos, S., Diekman, R., Lopez-Urrutia, A., Valdes, L., Carlotti, F., Molinero, J. C., Weikert, H., Greve, W., Lucic, D., Albaina, A., Daly Yahia, N., Fonda Umani, S., Miranda, A., dos Santos, A., Cook, K., Robinson, S., and Fernandez de Puelles, L. L.: An overview of Calanus helgolandicus ecology in European waters, Prog. Oceanogr., 65, 1-53, 2005.

Boucher, J., Ibañez, F., and Prieur, L.: Daily and seasonal variations in the spatial distribution of zooplankton populations in relation to the physical structure in the Ligurian Sea front, J. Mar. Res., 45, 133-173, 1987

Conte, M. H., Ralph, N., and Ross, E. H.: Seasonal and interannual variability in deep ocean particle fluxes at the Oceanic Flux Program (OFP)/Bermuda Atlantic Time Series (BATS) site in the western Sargasso Sea near Bermuda, Deep-Sea Res. Pt. II, 48, 1471-1505, 2001

Fowler, S. W. and Knauer, G. A.: Role of large particles in the transport of elements and organic compounds through the oceanic water column, Prog. Oceanogr., 16, 147-194, 1986.

Franqueville, C.: Macroplancton profond (invertébrés) de la Méditerranée nord-occidentale, Tethys, 3, 11-56, 1971.

Gasser, B., Payet, G., Sardou, J., and Nival, P.: Community structure of mesopelagic copepods $(>500 \mu \mathrm{m})$ in the Ligurian Sea (Western Mediterranean), J. Marine Syst., 15(1-4), 511-522, 1998.

Hure, J. and Scotto di Carlo, B.: Comparazione tra lo zooplancton del Golfo di Napoli e dell'Adriatico meridionale presso Dubrovnik, Pubbl. Staz. Zool. Napoli, 36, 21-102, 1968.

Ibañez, F., Fromentin, J.-M., and Castel, J.: Application de 
la méthode des sommes cumulées à l'analyse des séries chronologiques en océanographie, C. R. Acad. Sci. Paris, Sciences de la vie, 316, 745-748, 1993.

Jouenne, F., Lefebvre, S., Véron, B., and Lagadeuc, Y.: Phytoplankton community structure and primary production in small intertidal estuarine-bay ecosystem (eastern English Channel, France), Mar. Biol., 151, 805-825, 2007.

Keister, J. E. and Peterson, W. T.: Zonal and seasonal variations in zooplankton community structure off the central Oregon coast, 1998-2000, Prog. Oceanogr., 57(3-4), 341-361, 2003.

Kelly-Gerreyn, B. A., Hydes, D. J., Jégou, A. M., Lazure, P., Fernand, L. J., Puillat, I., and Garcia-Soto, C.: Low salinity intrusions in the western English Channel, Cont. Shelf Res., 26(11), 12 41-12 57, 2006.

Kiørboe, T.: Turbulence, phytoplancton cell size, and the structure of pelagic food webs, Adv. Mar. Biol., 29, 1-72, 1993.

Lasternas, S., Tunin-Ley, A., Ibañez, F., Andersen, V., Pizay, M.D., and Lemée, R.: Daily vertical abundance and diversity of microphytoplankton in NW Mediterranean Sea during the summer to autumn transition.(DYNAPROC II cruise; SeptemberOctober 2004), Biogeosciences Discuss., accepted, 2008.

Longhurst, A. R., Bedo, A., Harrison, W. G., Head, E. J. H., Horne, E. P., Irwin, B., and Morales, C.: Nflux - a Test of Vertical Nitrogen Flux by Diel Migrant Biota, Deep-Sea Res. Pt. I, 36, 17051719, 1989.

Mackas, D. L., Tsurumi, M., Galbraith, M. D. and Yelland, D. R: Zooplankton distribution and dynamics in a North Pacific Eddy of coastal origin: II. Mechanisms of eddy colonization by and retention of offshore species, Deep-Sea Res. Pt. II, 52(7-8), 10111035, 2005.

Marty, J.-C. and Chiavérini, J.: Seasonal and interannual variations in phytoplankton production at DYFAMED time-series station, northwestern Mediterranean Sea, Deep-Sea Res. Pt. II, 49, $2017-$ 2030, 2002.

Mazzocchi, M. G., Christou, E. D., Di Capua, I., Fernandez de Puelles, M. L., Fonda-Umani, S., Molinero, J.-C., Nival, P., and Siokou-Frangou, I.: Temporal variability of Centropages typicus in the Mediterranean Sea over seasonal-to-decadal scales, Prog. Oceanogr., 72, 214-232, 2007.

Mcgehee, D. E., Demer, D. A., and Warren, J. D.: Zooplankton in the Ligurian Sea: Part I. Characterization of their dispersion, relative abundance and environment during summer 1999, J. Plankton Res., 26(12), 1409-1418, 2004.

Mével, G., Vernet, M., Goutx, M., and Ghiglione, J. F.: Seasonal to hour variation scales in abundance and production of total and particle-attached bacteria in the open NW Mediterranean Sea (0$1000 \mathrm{~m})$, Biogeosciences, 5, 1573-1586, 2008, http://www.biogeosciences.net/5/1573/2008/.

Morgan, C. A., Peterson, W. T., and Emmet, R. L.: Onshoreoffshore variations in copepod community structure off the Oregon coast during the summer upwelling season, Mar. Ecol. Prog. Ser., 249, 223-236, 2003.

Mousseau, L., Lefevre, D., Andersen, V., Narcy, F., and Nival, P.:
Role of the zooplankton community composition on the mineralisation and the vertical flux of organic matter at a fixed station in the Ligurian Sea, Biogeosciences Discuss., accepted, 2008.

Pannard, A., Claquin, P., Klein, C., Le Roy, B., and Véron, B.: Short-term variability of the phytoplankton community in coastal ecosystem in response to physical and chemical conditions' changes, Estuar. Coast. Shelf S., 80, 212-224, 2008.

Perry, R. I. and Smith, J.: Identifying Habitat Associations of Marine Fishes Using Survey Data: An Application to the Northwest Atlantic, Can. J. Fish. Aquat. Sci., 51, 589-602, 1994.

Peterson, W.: Life cycle strategies of copepods in coastal upwelling zones, J. Marine Syst., 15(1-4), 313-326, 1999.

Pielou, E. C.: The measurement of diversity in different types of biological collections, J. Theor. Biol., 13, 131-144, 1966.

Pinca, S. and Dallot, S.: Meso- and macrozooplankton composition patterns related to hydrodynamic structures in the Ligurian Sea (Trophos-2 experiment, April-June 1986), Mar. Ecol. Prog. Ser., 126, 49-65, 1995.

Raybaud, V., Tunin-Ley, A., Ritchie, M. E., and Dolan, J.: Similar patterns of community organization characterize distinct groups of different trophic levels in the plankton of the Mediterranean Sea, Biogeosciences Discuss., 5, 4897-4917, 2008, http://www.biogeosciences-discuss.net/5/4897/2008/.

Razouls, C. and Durand, J.: Inventaire des copépodes planctoniques méditerranéens, Vie Milieu, 41, 73-77, 1991.

Razouls, C., de Bovée, F., Kouwenberg, J., and Desreumaux, N.: Diversité et répartition géographique chez les Copépodes planctoniques marins, http://copepodes.obs-banyuls.fr, 2005-2008.

Sameoto, D. D., Jaroszynski, L. O., and Fraser, W. B.: Bioness, a new design in multiple net zooplankton samplers, Can. J. Fish. Aquat. Sci., 37, 722-724, 1980.

Sardou, J., Etienne, M., and Andersen, V.: Seasonal abundance and vertical distributions of macroplankton and micronekton in the Northwestern Mediterranean Sea, Oceanol. Acta, 19, 645-656, 1996.

Shannon, C. E.: A mathematical theory of communications, AT\&T Tech. J., 27(379-423), 623-656, 1948.

Sournia, A., Brylinski, J.-M., Dallot, S., Le Corre, P., Leveau, M., Prieur, L., and Forget, C.: Fronts hydrologiques au large des cotes françaises: les sites ateliers du programme Frontal, Oceanol. Acta, 13, 119-,131, 1990.

Stewart, G., Cochran, J. K., Miquel, J.C., Masqué, P., Szlosek, J., Rodriguez y Baena, A. M., Fowler, S. W., Gasser, B., and Hirschberg, D. J.: Comparing POC export from $234 \mathrm{Th} / 238 \mathrm{U}$ and $210 \mathrm{Po} / 210 \mathrm{~Pb}$ disequilibria with estimates from sediment traps in the northwest Mediterranean, Deep-Sea Res. Pt. I, 54, 1549-1570, 2007.

Turner, J. T.: Zooplankton fecal pellets, marine snow and sinking phytoplankton blooms, Aquat. microb. Ecol., 27, 57-102, 2002.

Vives, F.: Sur les copépodes néritiques (Calanoida) de la Méditerranée occidentale, Rapp. et P. V. Cons. I. Explor. Mer, 17, 547-554, 1963. 